\title{
OTKUP KNJIGA MINISTARSTVA KULTURE I MINISTARSTVA ZNANOSTI, OBRAZOVANJA I SPORTA - UTJECAJ NA IZGRADNJU KNJIŽNOG FONDA GRADSKE I SVEUČILIŠNE KNJIŽNICE OSIJEK U RAZDOBLJU OD 1998. DO 2013.
}

\author{
GOVERNMENT PURCHASE OF BOOKS BY \\ THE MINISTRY OF CULTURE AND THE MINISTRY OF \\ SCIENCE, EDUCATION AND SPORTS - THE IMPACT ON \\ COLLECTION BUILDING OF THE CITY AND UNIVERSITY \\ LIBRARY OSIJEK IN THE PERIOD FROM 1998 TO 2013
}

\section{Ljiljana Siber ${ }^{1}$}

Sveučilište u Osijeku, Pravni fakultet Osijek

ljsiber@pravos.hr

Srđan Lukačević

Sveučilište u Osijeku, Gradska i sveučilišna knjižnica Osijek slukacevic@gskos.hr

UDK / UDC

025.22:027.3"1998/2013"(497.5 Osijek)

Izvorni znanstveni rad / Original scientific paper Prihvaćeno / Accepted: 9. 4. 2017.

\section{Sažetak}

Rad predstavlja istraživanje o važnosti, udjelu i utjecaju otkupa Ministarstva kulture i Ministarstva znanosti, obrazovanja i sporta na izgradnju fonda Gradske i sveučilišne

1 Ovaj je rad nastao na temelju diplomskog rada Ljiljane Siber, pod mentorstvom prof. dr. sc. Srećka Jelušića, no znatno mu je prošireno istraživano razdoblje (za dvanaest godina) te je osuvremenjen recentnim podacima i znanstveno-stručnim promišljanima.

Vjesnik bibliotekara Hrvatske 60, 2-3(2017), 79-109

ISSN 0507-1925

(C) VBH 2017. 
knjižnice Osijek. Prvi dio sadrži teorijska razmatranja temeljena na stručnim standardima, načelima vezanim uz izgradnju zbirki, potrebama korisnika, dostupnosti pisane riječi te utjecaju otkupa na promicanje i stvaranje kulture čitanja. Nadalje se u teoriji daje kratak povijesni prikaz primjene otkupa dvaju ministarstava kao jednog od načina nabave građe za knjižnice.

Drugi dio rada daje analizu otkupljene građe tijekom istraživanoga razdoblja u kojem su prikazani podaci o knjigama namijenjenim odraslim korisnicima, kao i onim namijenjenim djeci. Uz statističke smo podatke utvrdili brojne pozitivne, ali i znatne negativne aspekte poslovanja Knjižnice promatrane u perspektivi otkupa knjiga od strane dvaju ministarstava.

\section{Summary}

The paper is a study about the importance and influence of the book purchase by the Croatian Ministry of Culture and the Ministry of Science, Education and Sports on collection building in the City and University Library in Osijek. The first part discusses the theoretical considerations based on the professional library standards, principles related to collection building, user needs, the availability of the written word, and the impact of the government book purchase policy on promoting and creating the culture of reading. Furthermore, the theoretical part provides a brief historical overview of the use of book purchase by the Ministries as one of the ways of library materials acquisition.

The second part of the paper provides an analysis of the items purchased through the researched period and presents the data about the books for adults and the books for children. The statistical data gained from this study, through the analysis of the book purchase by the Ministries, have shown many positive, but also a number of negative aspects of the Library management.

Keywords: City and University Library Osijek, acquisition, purchase of books, research, public library, university library

\section{Uvod}

Gradska i sveučilišna knjižnica Osijek (u daljnjem tekstu: GISKO) djeluje kao tradicionalna ${ }^{2}$ i suvremena knjižnica u nacionalnom knjižničnom sustavu. Na dobrobit članova svoje korisničke zajednice promiče njihovo pravo na nesmetan pristup informacijama i idejama te sudjeluje u jačanju svijesti i obaviještenosti građana, što je temelj svakog demokratskog društva. Da bi mogla ispuniti svo-

2 U knjižničnom smislu - knjižnica u funkciji spomenika i čuvanja nacionalne i kulturne baštine. 
je funkcije i zadaće središnje sveučilišne/znanstvene knjižnice ${ }^{3}$ Sveučilišta Josipa Jurja Strossmayera u Osijeku i središnje (matične) javne/narodne knjižnice ${ }^{4}$ Grada Osijeka, Županije osječko-baranjske, teži planskom popunjavanju svojih fondova relevantnim naslovima knjiga i druge građe s brojem primjeraka primjerenim i prilagođenim interesima svojih korisnika.

Zbog svega navedenog važno je utvrditi utjecaj koji je otkup knjiga Ministarstva kulture i, manjim dijelom, Ministarstva znanosti, obrazovanja i sporta tijekom razdoblja od 1998. do 2013. godine imao na izgradnju zbirki Gradske i sveučilišne knjižnice Osijek. U obavljanju svoje djelatnosti GISKO nastoji izgrađivati fond u skladu sa zacrtanim smjernicama za nabavu s jasnom svrhom i ciljevima. U skladu sa svojom funkcijom i zadaćom narodne i znanstvene knjižnice, primjenjuje Standarde za narodne knjižnice Republike Hrvatske i Standarde za visokoškolske ustanove te djeluje u okviru dokumenata međunarodne zajednice - Opće deklaracije o ljudskim pravima, IFLA-ine Izjave o slobodi pristupa informacijama, Izjave o intelektualnim slobodama, slobodnom pristupu knjižničnim zbirkama, UNESCO-ova Manifesta za narodne knjižnice te prihvaćanja Međunarodne konvencije o copyrightu. U odnosu na trenutačno stanje, uvjete djelovanja i financijske mogućnosti, osnovni pravci razvoja Knjižnice određeni su dvojako, i to kratkoročno - kontinuitet dvojne djelatnosti - te dugoročno - osamostaljivanje i razdvajanje navedenih funkcija do, vjerujemo, skorašnjeg potpunog fizičkog odvajanja na dvije zasebne ustanove: gradsku knjižnicu kao javnu narodnu knjižnicu općeznanstvenog tipa te sveučilišnu knjižnicu.

Kako ovaj rad analizira otkup ${ }^{5}$ kao sastavni dio i jedan od vidova nabave izgradnje knjižnog fonda GISKO-a i njegova utjecaja na kvalitetu i kvantitetu složenog procesa njegove izgradnje, treba se osvrnuti na teorijski pristup izgradnji knjižnih zbirki koji je temelj svake suvremene knjižnice. U nastavku rada razradit će se taj vid nabave i ocijeniti postojeće stanje.

\footnotetext{
3 Zakonom o visokim učilištima, čl. 178, osnivačka i vlasnička prava nad knjižnicom prenesena su na Sveučilište J. J. Strossmayera u Osijeku. Navedenim Zakonom knjižnica je definirana kao ustanova čija djelatnost osigurava cjelovitost i potreban standard sustava visoke naobrazbe na sveučilištu, a u knjižničnom smislu kao sveučilišna/znanstvena knjižnica.

Zakon o visokim učilištima (pročišćeni tekst).//Narodne novine 59, 1187(1996). [citirano:2017-09-04]. Dostupno na http://narodne-novine.nn.hr/clanci/sluzbeni/1996_07_59_1187.html.

4 U skladu s odredbama Zakona o knjižnicama, čl. 9 - „Općina i gradovi dužni su osnovati narodnu knjižnicu kao javnu ustanovu osim u slučaju kada djelatnost narodne knjižnice već ne obavlja koja sveučilišna ili općeznanstvena knjižnica na njihovom području“ - sklopljen je Ugovor između Grada Osijeka - Poglavarstva i Sveučilišta J. J. Strossmayera u Osijeku s jedne strane te GISKO-a s druge. Usp. Zakon o knjižnicama. // Narodne novine 105, 1616(1997). [citirano: 2017-09-04]. Dostupno na http://narodne-novine.nn.hr/clanci/sluzbeni/1997_10_105_1616.html.

5 Kada je riječ o knjigama, mogli bismo otkup vezati uz npr. pomoć države da neka knjižnica kupi vrijedna izdanja. Značenje koje nudi Anićev Rječnik hrvatskoga jezika, Zagreb: Novi Liber, 1994., str. 622, glasi: „Otkup 1. ugovorom utvrđen iznos kojim se što otkupljuje, kojim što mijenja vlasnika. 2. preuzimanje viška poljoprivrednih proizvoda uz garantiranu novčanu naknadu.“
} 


\section{Izgradnja knjižničnih zbirki}

Zbirke su komplementarne sa službama i uslugama i stoga ne bi smjele biti cilj same po sebi, osim kada je njihova specifična osnovna uloga zaštita i čuvanje građe za buduće naraštaje. Veličina zbirke ne jamči nužno i da je riječ o kvalitetnoj zbirci. Relevantnost zbirke za potrebe lokalne zajednice važnija je od njezine veličine. Izgradnji dobre zbirke prethode pomno razrađeni postupci: od istraživanja zajednice korisnika i njezinih potreba, preko kvalitetnog kreiranja nabavne politike i selekcije ili odabira knjižne građe, do postupaka nabave ${ }^{6}$, evaluacije i pročišćavanja zbirki. Također, P. Clayton i G. Gorman u svom djelu Managing Information Resources in Libraries ${ }^{7}$ ističu važnost sustavnog dokumentiranja izgradnji knjižničnih zbirki u teoriji i praksi. Autori tvrde kako je za učinkovito upravljanje fondom neophodan usvojeni program izgradnje zbirke/fonda, jer je on podskup cjeline upravljanja fondom. Program izgradnje zbirke/fonda samo je dio programa upravljanja fondom knjižnice, a skup je stavova o općim načelima izgradnje zbirke/fonda koja oslikava svrhu i sadržaj fonda koji je namijenjen podjednako zaposlenima i javnosti (korisnicima).

U skladu s navedenim, nabavna politika mora biti skup konkretnih uputa o tome kakvim sadržajima i formalnim kriterijima knjižnica popunjava svoje zbirke i na koji način to realizira. ${ }^{8}$ Nabavna politika GISKO-a proizlazi iz zadataka i namjene same knjižnice. Usklađuje se i korigira u okvire koje određuju Standardi za narodne knjižnice u Republici Hrvatskoj ${ }^{9}$, Standardi za visokoškolske knjižnice u Republici Hrvatskoj ${ }^{10}$, Smjernice za nabavu, veličina populacije na području koje knjižnična služba obuhvaća, blizina drugih knjižnica, regionalna uloga zbirki, procjena lokalnih potreba, nakladnička ponuda i financijske mogućnosti. Da bi odgovorile na zahtjeve korisnika, knjižnične zbirke trebaju sadržavati raznovrsnu građu bez obzira na vrstu, formate i medije, a dijele se na knjige, periodiku (novine, časopise i dr.), polupublikacije (uključujući službene publikacije), NBM (neknjižna građa), mikrooblike, audio-vizualnu građu, digitalnu građu, online baze podataka, magnetne medije i optičke diskove, igre i igračke, građu za slijepe i slabovidne osobe te grafičke mape. Načela knjižničnog poslovanja predlažu četiri načina nabave knjižnične građe, među kojima je kupnja kao oblik nabave građe najzastupljenija u svim knjižnicama. Po tome se vidi je li nabavna politika vođena

\footnotetext{
6 Predakcesija i akcesija.

7 Clayton, Peter; Gary E. Gorman. Managing information resources in libraries : Collection management in theory and practice. London : Library Association Publishing, 2001. Str. 52-72.

8 Leonhardt, Thomas. The gifts and exchange function in ARL libraries : now and tomorrow. // Library Acquisitions: Practice \& Theory 21, 2(1997), 141-149.

9 Standardi za narodne knjižnice u Republici Hrvatskoj. // Narodne novine 58, 1071(1999).[citirano: 2017-09-04]. Dostupno na http://narodne-novine.nn.hr/clanci/sluzbeni/1999_06_58_1071.html.

10 Standard za visokoškolske knjižnice u Republici Hrvatskoj. // Vjesnik bibliotekara Hrvatske 33, 1-4(1990), str. 201-210.
} 
dobro ili loše. Kako su financijska sredstva uglavnom ograničena, stručni djelatnici kupnju usmjeravaju prema dobavljačima koji nude najpovoljnije uvjete, što s druge strane predstavlja problem malim nakladnicima. ${ }^{11}$ Zamjenu knjižnične građe knjižnice obavljaju s drugom knjižnicom ili srodnom ustanovom u gradu, državi, pa i u inozemstvu. Darovi kao treća vrsta nabave pristižu u knjižnicu od ustanova, korisnika ili drugih osoba, uglavnom željom darovatelja (slučajni), ali mogu biti i izazvani ako knjižničar zamoli pojedinca ili ustanovu da daruje određenu građu. Posebna vrsta dara je legat, odnosno oporučno ostavljena vlastita knjižnica koju pojedinac daruje određenoj knjižničnoj ustanovi. GISKO posjeduje posebne zbirke legate: Hengl, Sonnenfeld, Magjer, Pollak, Rakoš, Pinterović, Kocijan, Gottschalk i dr. Kao četvrta vrsta nabave navodi se obvezni primjerak, što je zakonski ${ }^{12}$ propisan način prikupljanja publikacija prema kojem su proizvođači (nakladnici/tiskari) javno dostupnih publikacija s područja određene države (administrativne jedinice) dužni besplatno, u potpunosti i redovito dostavljati određeni broj primjeraka označenoj knjižnici, koja je dužna čuvati ih i omogućiti njihovu dostupnost sada i u budućnosti. Četiri su glavna vida, odnosno funkcije obveznog primjerka: potpunost, očuvanje, informiranje i dostupnost.

Postavlja se pitanje prema čemu se otkup kao način nabave razlikuje od ostalih navedenih oblika. U svim navedenim oblicima važan je odabir i utjecaj knjižnice u oblikovanju vlastitih zbirki, a otkup, ako nije unaprijed dogovoren sa svakom knjižnicom, jest popunjavanje fondova bez njezina utjecaja.

\section{Osnovna načela i pristup izgradnji fondova}

Kako GISKO obavlja funkcije i zadaće narodne i znanstvene/sveučilišne knjižnice, u pristupu izgradnji svojih fondova stručno osoblje nema nimalo zahvalan posao. Kako smo već naveli, okvire joj određuju Standardi za narodne knjižnice, a s druge strane Standardi za visokoškolske ustanove, držeći se zacrtanih načela njegove izgradnje.

\footnotetext{
11 Problem imaju tzv. mali nakladnici koji zbog manjeg broja nakladničkih primjeraka ne mogu konkurirati „velikima“, koji u svakom slučaju mogu ponuditi bolje uvjete.

12 Zakon o knjižnicama. Nav. dj., čl. 37.: „Pravna ili fizička osoba koja izdaje ili proizvodi građu iz čl. 38. ovog Zakona namijenjenu javnosti, dužna je od te građe besplatno i o svom trošku, a najkasnije u roku od 30 dana po završetku tiskanja, umnažanja ili proizvodnje, dostaviti Nacionalnoj i sveučilišnoj knjižnici u Zagrebu osam obveznih primjeraka, od kojih Nacionalna i sveučilišna knjižnica u Zagrebu zadržava dva, a po jedan primjerak dostavlja sveučilišnim knjižnicama u Splitu, Rijeci, Puli i Osijeku, kao i u Mostaru te općeznanstvenim knjižnicama u Dubrovniku i Zadru. Svaki nakladnik dužan je u roku iz stavka 1. ovog članka dostaviti još po jedan primjerak građe matičnoj knjižnici na području županije na kojoj je njegovo sjedište radi stvaranja zavičajne zbirke.“
} 
„Izgradnja zbirke u knjižnici treba se temeljiti na neovisnoj stručnoj procjeni knjižničara, bez političkog, sektaškog, tržišnog ili kakvoga drugog utjecaja, uz savjetovanje s predstavničkim tijelima korisnika, skupinama zajednice te s obrazovnim, informacijskim i kulturnim ustanovama. Politiku izgradnje zbirke treba neprekidno preispitivati da bi valjano odražavala promjene u potrebama i mogućnostima. Izgradnja zbirke treba biti transparentan proces, a politika na kojoj se ona temelji mora biti javna. Knjižnice trebaju biti dio sustava u zemlji, surađivati u nabavi i uspostaviti usku radnu vezu s drugim kulturnim, obrazovnim i informacijskim ustanovama omogućavajući pristup građi koja nije dio knjižnične zbirke bilo putem međuknjižnične posudbe u zemlji i inozemstvu, bilo sustavom dostave dokumenata, uključujući uporabu elektroničkih informacijskih službi i umreženih informacija."

Tu problematiku iznosi i Peleš ${ }^{14}$ kada govori o izgradnji znanstvenih zbirki i važnosti usklađenosti među dionicima procesa. Narodne knjižnice, bez obzira na veličinu, svoje zbirke trebaju uskladiti s potrebama svojih korisnika i njihovim zahtjevima te ih prilagoditi svim dobnim skupinama. Važno je sagledavati potrebe cjelokupne lokalne zajednice i ne ograničiti se samo na zahtjeve aktivnih korisnika. Zbirka se mora stvarati stručno te uz tradicionalnu građu obuhvaćati i sve vrste nositelja obavijesti. Izgradnja zbirki bila je i bit će podložna osobnim procjenama izbornika i osoba koje procjenjuju vrijednost zbirke. Uz teorijska znanja, iskustvo je bitan čimbenik koji proizlazi iz izravnog kontakta s korisnicama. Planirana struktura nabave pridonosi kvaliteti izgradnje fonda, koja je preporučena Standardima za narodne knjižnice. U čl. 19. navodi se:

„Knjižnični fond općinske ili gradske narodne knjižnice treba sadržavati (u broju svezaka): $45 \%$ beletristike, $25 \%$ znanstvene i popularno-znanstvene literature, $27 \%$ literature za djecu i $3 \%$ priručne literature. Županijska narodna knjižnica treba imati $45 \%$ znanstvene literature, $35 \%$ beletristike, $15 \%$ dječje i $5 \%$ priručne literature. “15

Standardi također predviđaju postojanje pisanog godišnjeg, srednjoročnog i dugoročnog plana nabave na temelju kojega se određuje vrsta i količina knjižnične građe koja se nabavlja. Ako i ne postoje konkretni pisani planovi nabave, svaka knjižnica, pa tako i GISKO, ima nabavnu politiku utvrđenu u Smjernicama.

13 Preporuke za knjižnično zakonodavstvo i politiku u Europi. // Vjesnik bibliotekara Hrvatske 43, 3(2000), str. 162.

14 Peleš, Gajo. Nabavna politika kao pokazatelj odnosa između sveučilišnih (fakultetskih) biblioteka i Nacionalne i sveučilišne biblioteke. // Vjesnik bibliotekara Hrvatske 33, 1/4(1990), str. 53-56.

15 Standardi za narodne knjižnice u Republici Hrvatskoj. Nav. dj. 
Nabavna je politika promišljena aktivnost u koju su uključeni svi stručni djelatnici knjižnice. Važna je analiza korisnika procjenjivanih na osnovi njihove strukture te njihovih pojedinačnih zahtjeva pri dolasku u knjižnicu. Obrazovna, kulturna, stručna i informacijska razina potreba korisnika te podizanje kvalitete društvenog standarda i ostvarivanje demokratskih prava omogućavanjem slobodnog pristupa informacijama vodilja su u kreiranju i pristupu fondovima knjižnica. Naravno da se sve navedene aktivnosti korigiraju i usklađuju s aktualnim financijskim mogućnostima knjižnice i nakladničkom ponudom.

\section{Načela i pristup izgradnji fondova sa stajališta znanstvenih/sveu- čilišnih knjižnica}

Sveučilište u svojoj obrazovnoj funkciji ima i posebno važno mjesto u prijenosu znanja, ali ništa manje nije važna ni njegova uloga u sustavu znanstvenih komunikacija.

„Snaga sveučilišnih biblioteka (i bibliotekarstva uopće) proizlazi iz njihovih dviju temeljnih funkcija: funkcije prikupljanja i funkcije čuvanja materijalnih nosilaca na kojima je bilježeno znanje i iskustvo čovječanstva. Ove su funkcije toliko bitne da na njihovu učinkovitom otkrivanju počiva značajan dio razvoja znanosti i civilizacijskih tekovina uopće. “16

„Knjižnica općenito pohranjuje i čini dostupnim sve što posjeduje te omogućuje pristup drugim izvorima. Znanstvena knjižnica na sveučilištu, međutim, nastoji učiniti i nešto više od toga. Ona nudi znanstvenicima sredstva koja će im pomoći da reorganiziraju prikupljene informacije i stoga ona pomaže da se proširi zaliha znanja; ona pomaže generiranju novih znanja i njihovu prijenosu na nove naraštaje. Skloni smo ustvrditi da bez velikih, bogatih zbirki, bez stručnjaka koji će usmjeravati i upućivati korisnike, nove tehnologije imaju vrlo ograničeno djelovanje." ${ }^{\text {17 }}$

Treba istaknuti podatak da su korisnici tih knjižnica visokoobrazovani kadrovi: nastavnici, stručni suradnici na sveučilištima, magistri ili doktori znanosti, koji su obvezni neprestano se stručno usavršavati, kao i studenti. Fondovi knjižnica trebaju osiguravati dostupnost građe koja zadovoljava potrebe korisnika. Važno je da zbirka pokriva potrebe akademskog programa, što treba biti razvidno iz jav-

\footnotetext{
16 Aparac-Jelušić, Tatjana. Sveučilišni bibliotečni sustavi u teoriji i praksi. // Vjesnik bibliotekara Hrvatske 33, 1-4(1990), str. 44.

17 Aparac-Jelušić, Tatjana. Utjecaj promjena u akademskom obrazovanju na preoblikovanje knjižnih službi i usluga.// Glasnik društva bibliotekara Split 7(2000), str. 49.
} 
nog očitovanja knjižnice o svrsi i ciljevima njezina djelovanja te iz pisanog plana nabave. ${ }^{18} \mathrm{U}$ pristupu izgradnji fondova treba procijeniti potrebe, zahtjeve i međuovisnosti akademske zajednice. Prema Gardnerovim kriterijima koje navodi Tatjana Aparac-Jelušić u predavanju Izgradnja i upravljanje knjižničnim fondom ${ }^{19}$

„....treba voditi računa da ocjenjujemo građu s obzirom na reputaciju autora i izdavača, o stupnju točnosti prezentiranih informacija (potrebno je mišljenje eksperta), nepristranosti, odnosno jesu li pitanja i rasprava predstavljeni bez pristranosti te o stupnju novosti informacija. Nadalje, u odabiru građe treba poštivati dubinu pokrivenosti nekog područja i odgovarajuću korisničku razinu. Djela u takvim knjižnicama moraju biti relevantna za korisnikovo iskustvo te njegov interes. Interes će svakako biti veći ako su odabrana djela u zbirkama logično prezentirana i ako korespondiraju s postojećim zbirkama. Treba racionalno procijeniti ima li što jeftinije od građe koju želimo nabaviti, a da pokriva isto područje ili predmet koji želimo obuhvatiti, koliko je razumno utrošiti sredstva ako se predviđa da se naslov neće koristiti u dovoljnoj mjeri, koliko je ‘trajan' materijal predstavljen u knjizi i hoće li uskoro zastarjeti.“

Cilj sustavne nabavne politike jest utvrditi i učinkovito zadovoljiti potrebe korisnika uz racionalno trošenje osiguranih sredstava. U tom se postupku od knjižničara očekuju stručne, organizacijske i menadžerske vještine. ${ }^{20}$

Prema Standardima za visokoškolske knjižnice treba „na razini sveučilišta usklađivati nabavu stručne i znanstvene literature interdisciplinarnog i multidisciplinarnog sadržaja, temeljnih znanstvenih djela, stranih časopisa i referentnih publikacija; u tu svrhu sveučilišna knjižnica vodi i održava središnju dezideratu, izrađuje liste prinova i preporučene liste..." Nabava knjižnične građe podrazumijeva poznavanje znanstvenog/stručnog područja u kojem knjižnica djeluje te poznavanje značajnih izvora informacija za to područje. Prema Sherai, nabava knjižnične građe ,znači prvo znati što treba nabaviti, a to je definirano korisničkim ili pretpostavljenim korisničkim potrebama, te zatim znati gdje i kako se to može nabaviti. ${ }^{21}$ Sveučilišna knjižnica prima, obrađuje, pohranjuje i daje na korištenje doktorske i magistarske radove obranjene na matičnom sveučilištu.

18 Dragija, Martina; Tatjana Aparac-Jelušić. Pristup i metodologija istraživanja o kvaliteti zbirki u knjižnicama visokih učilišta. // Glasnik Društva bibliotekara Split 7(2000), str. 164-165.

19 Aparac-Jelušić, Tatjana. Izgradnja i upravljanje knjižničnim fondom: predavanje. Rijeka, 2003. [citirano 2017-04-08]. Dostupno na https://goo.gl/3i8UPC.

20 Lewis, Janice S. An assessment of publisher quality by political science librarians. // College \& Research Libraries 61, 4(2000), 313-323.

${ }^{21}$ Shera, Jesse. H. Introduction to library science. Littleton, Colorado : Libraries Unlimited, 1976. Str. 66. Citirano prema: Sečić, Dora. Neki suvremeni pogledi na nabavnu politiku u znanstvenim bibliotekama u SAD i Evropi. // Informatologia Yugoslavica 20, 3/4(1988), str. 200. 
Osnovni fond sveučilišne knjižnice treba sadržavati minimalno 200000 svezaka omeđenih publikacija te 2000 naslova tekuće periodike, od toga najmanje 60 $\%$ inozemne. Godišnji prirast kupljene građe u sveučilišnoj knjižnici treba biti najmanje jedan svezak omeđenih publikacija po svakom upisanom korisniku.“ $U$ zbirkama tih knjižnica sve će veće značenje imati elektronički izvori, naročito oni vezani uz učenje na daljinu, ali, naravno, upravljanje i razvoj zbirki tiskane građe ne gube na važnosti.

\section{Otkup knjiga}

Budući da je otkup knjiga vrlo šturo opisan u teorijskoj literaturi, bit će zanimljivo prikazati kako je on postao standardizirani način nabave za narodne knjižnice. Otkup kao oblik nabave zabilježen je 1990. godine u Standardima za narodne knjižnice Republike Hrvatske, a ponovljen je i u novijem tekstu Standarda donesenog 1999. godine u čl. 25.: „Prosječni standard prinove knjiga u tekućoj godini (kupnjom, obveznim primjerkom, darovima, zamjenom i otkupom)...“ IFLA-ini standardi za narodne knjižnice oblike nabave u narodnim knjižnicama uopće ne navode, pa možemo smatrati da oblici nabave ne izlaze iz okvira propisanih općom teorijskom literaturom. Otkup knjiga jedan je oblik poticanja i pomaganja države nakladničkoj djelatnosti. U nas je otkup poznat više od dvadeset godina. Nekadašnji RSIZ-ovi kulture preko mjerodavnih su tijela dodatno financirali pojedine naslove natječajem za tzv. društveno vrijednu knjigu. Raspadom Jugoslavije, 90-ih godina, Ministarstvo kulture Republike Hrvatske nastavilo je takvo dodatno financiranje te je uz financiranje prijavljenih rukopisa uključivalo i otkup objavljenih djela, koja su potom slana u narodne knjižnice. Tako se na državnoj razini uobičajio otkup Ministarstva kulture i Ministarstva znanosti, obrazovanja i sporta te otkup na lokalnoj razini, tj. na razini pojedinih gradova. Ministarstvo kulture Republike Hrvatske na temelju Zakona o financiranju javnih potreba u kulturi (Narodne novine, broj 47/1990, 27/1993 i 38/2009), Zakona o državnim potporama (Narodne novine, broj 72/2013 i 141/2013), Pravilnika o izboru i utvrđivanju programa javnih potreba u kulturi (Narodne novine, broj 69/2012, 44/2013 i 91/2013) i Ugovora o funkcioniranju EU-a, (članak 107., stavak 3., točka d) svake godine raspisuje javni poziv za podnošenje ponuda za otkup knjiga i potporu izdavanju knjiga. Jedan od osnovnih ciljeva tog načina potpore otkup je knjiga za narodne knjižnice, ali sa svrhom potpore izdavaštvu, kao i izravna potpora nakladnicima u sufinanciranju pojedinih vrijednih knjiga. Ministarstvo kulture otkupljuje izdanja domaćih izdavača, i to djela od temeljne vrijednosti za nacionalnu kulturu, znanost i umjetnost, djela prevedena s jezika drugih naroda koja predstavljaju opća kulturna dostignuća, sabrana i odabrana djela hrvatskih književnika, djela koja prikazuju aktualno domaće umjetničko i publicističko stvaralaštvo, kao i djela koja pridonose boljem upoznavanju razli- 
čitih kultura, djela hrvatskih autora u prijevodu na strane jezike, ali ne otkupljuje udžbenike, popularna i komercijalna izdanja. ${ }^{22}$

\subsection{Otkup Ministarstva znanosti, obrazovanja i sporta}

Nekadašnje Ministarstvo znanosti i tehnologije, a sada Ministarstvo znanosti, obrazovanja i sporta, dugi niz godina novčano podupire znanstvenoizdavačku djelatnost knjiga i časopisa. Kriteriji za dodjelu obuhvaćaju novčano podupiranje znanstvene i visokoškolske izdavačke djelatnosti, izdavanje visokoškolskih udžbenika, znanstvenih knjiga, znanstvenih i znanstveno-stručnih časopisa za promicanje znanosti. Odluke o novčanom podupiranju donosi ministar na temelju stručne prosudbe Povjerenstva za izdavačku djelatnost, koje je savjetodavno tijelo ministra. ${ }^{23} \mathrm{Uz}$ navedeno, znanstvenom i visokoškolskom izdavačkom djelatnošću obuhvaćen je i otkup visokoškolskih udžbenika i znanstvenih knjiga namijenjen knjižnicama visokoškolskih i znanstvenih ustanova. Budući da smo otkup knjiga naveli kao jedan od načina pomoću kojih knjižnica obogaćuje svoj knjižni fond, potrebno je navesti kriterije koje treba ispuniti prema Ministarstvu da bi se knjiga smatrala znanstvenom.

„Znanstvenom knjigom smatra se: znanstvena autorska knjiga jednog
ili više autora koja donosi rezultate znanstvenih istraživanja; znan-
stvena urednička knjiga (zbirka tekstova jednog ili više autora, zbor-
nik sa znanstvenoga skupa i sl.); znanstveno referentno djelo: enci-
klopedija, leksikon, rječnik, gramatika, pravopis, priručnik, povijesni
pregled, arhivska građa i sl.; kritičko izdanje djela prema izvorniku,
djelo na starohrvatskome i obrada starohrvatskih (staroslavenskih) je-
zika; djelo za promicanje znanosti (znanstveno-popularno djelo).“24

Ministarstvo znanosti, obrazovanja i sporta objavljuje na početku godine javni natječaj za novčanu potporu, među ostalim namjenama, i za otkup znanstvenih knjiga i visokoškolskih udžbenika. Nakon zaključenog natječaja Povjerenstvo za izdavačku djelatnost pri Ministarstvu nakon izvršenog odabira sklapa ugovor s izdavačima o otkupu ponuđenih naslova. Od 2001. godine Ministarstvo dostavlja popise znanstvenim i visokoškolskim knjižnicama i ustanovama s ponuđenim naslovima. Kako smo već naveli, GISKO obavlja dvojnu funkciju - narodne i znanstvene/sve-

\footnotetext{
22 Javni poziv za predlaganje programa književne, nakladničke i knjižarske djelatnosti za 2014. godinu u okviru programa javnih potreba u kulturi Republike Hrvatske [citirano: 2017-04-08]. Dostupno na http://www.min-kulture.hr/novost/default.aspx?id=10387.

23 Izdavačka djelatnost, skupovi, udruge i programi popularizacije znanosti [citirano: 2017-0408]. Dostupno na http://public.mzos.hr/Default.aspx?art=14718.

24 Kriteriji za financijsku porporu izdavanja znanstvenih knjiga. [citirano: 2017-04-08]. Dostupno na https://mzo.hr/sites/default/files/migrated/kriteriji_2015.pdf.
} 
učilišne knjižnice - te je obuhvaćen tom vrstom otkupa. Nakon što je popis dostavljen, GISKO odabire željene naslove i odgovarajući broj primjeraka koji je u skladu s njegovom definiranom nabavnom politikom. U analizi primjeraka i naslova pristiglih tim načinom nabave vidjet ćemo kako njihova količina postupno opada.

Tablica 1. Knjige pristigle otkupom Ministarstva znanosti, obrazovanja i sporta u razdoblju od 1998. do 2006. godine

\begin{tabular}{|c|c|c|}
\hline Godina & Broj naslova & Broj primjeraka \\
\hline 1998. & 98 & 113 \\
\hline 1999. & 40 & 253 \\
\hline 2000. & 32 & 124 \\
\hline 2001. & 1 & 20 \\
\hline 2002. & 58 & 161 \\
\hline 2003. & 431 & 431 \\
\hline 2005. & 172 & 338 \\
\hline 2006. & 41 & 41 \\
\hline
\end{tabular}

Kako je vidljivo iz tablice 1, u GISKO-u je tim načinom 2003. godine pristiglo najviše naslova, dok je 2001. godine otkupljen samo jedan naslov, ali u 20 primjeraka. U 2000. godini broj primjeraka nešto je manji (4-5), dok je u 2002. godini taj broj smanjen u prosjeku na tri primjerka po naslovu. Godina 2006. posljednja je godina u kojoj je prema knjigama inventara GISKO-a evidentirano pristizanje građe preko otkupa Ministarstva znanosti, obrazovanja i sporta.

\subsection{Otkup knjiga lokalne zajednice}

Taj način potpore uvjetovan je uglavnom društvenim standardom određene lokalne zajednice. Otkup je najuže povezan s nedostatkom novca za nabavu knjiga. Tako od osamdesetih godina Gradsko poglavarstvo grada Zagreba kupuje od izdavača veći broj primjeraka knjiga prema vlastitom izboru i šalje ih narodnim knjižnicama u Zagrebu. Knjižnice uglavnom ne znaju prema kojim kriterijima Komisija za otkup knjiga unutar Gradskog poglavarstva odlučuje koji će se naslovi kupiti i u koliko primjeraka. U odnosu na Grad Osijek koji se javlja kao financijer narodne djelatnosti, GISKO nema takav način potpore. Namjenska sredstva za nabavu knjižne građe ne specificira kao određeni iznos, nego ih dostavlja kumulativno, u cjelokupnom iznosu, a onda se iz tih sredstava u knjižnici raspoređuju sredstva namijenjena za nabavu knjižne građe. Kako lokalna zajednica nema nikakvu obvezu, GISKO povremeno od Županije potražuje novčana 
sredstva za nabavu knjižne građe $i$, ako udovolji zahtjevu, stručni djelatnici za ta sredstva sami kupuju potrebne naslove. Iz navedenoga možemo zaključiti da se otkup knjiga na razini lokalne zajednice kao takav nije uobičajio i ne predstavlja značajniji doprinos izgradnji knjižnog fonda GISKO-a.

\section{Otkup knjiga Ministarstva kulture u razdoblju od 1998. do 2013.}

Ministarstvo kulture raspisuje natječaj na koji se izdavači odazivaju nudeći svoje naslove. Godine 1998. izabrano je Povjerenstvo za nakladništvo i otkup knjiga Ministarstva kulture sastavljeno od uglednih književnih i kulturnih djelatnika koji su se sastajali u određenom vremenskom razmaku. Tako sastavljeno Povjerenstvo odlučivalo je o odabiru naslova pristiglih na natječaj i o njihovu otkupu u 50, 100 i 250 primjeraka koji su distribuirani u knjižnice prema ključu koji ćemo objasniti u nastavku rada. Iako su u rad Povjerenstva uključeni istaknuti stručnjaci, knjižničarska struka nije bila zadovoljna i zahtijevala je da se i knjižničari uključe u rad Povjerenstva, pa su od 1999. godine njegovim dijelom postali i stručni djelatnici narodnih knjižnica. Broj članova Povjerenstva varirao je: od nekadašnjih sedam, danas Povjerenstvo čini pet članova. ${ }^{25}$ Zadatak je članova Povjerenstva utvrditi kriterije za promidžbu hrvatske pisane riječi pomoću potpore nakladnicima u izdavanju knjiga i drugih publikacija te otkupa knjiga za potrebe narodnih knjižnica. Ovisno o broju otkupljenih naslova, raspodjela primjeraka ne uključuje sve knjižnice u Hrvatskoj. Također, s početnom godinom istraživanja (1998.) Ministarstvo je odredilo da matične knjižnice u svojim županijama distribuiraju knjige prispjele od izdavača knjižnicama na svom području. Za područje Osječko-baranjske županije tu je zadaću obnašala Gradska i sveučilišna knjižnica Osijek sve do 2000. godine, nakon čega otkupljene knjige u knjižnice pristižu izravno od izabranih izdavača. Iste godine mijenja se i broj naslova i primjeraka te je tako minimalan broj otkupljenih primjeraka 20, a maksimalan 300 . U istoj godini pojačano se otkupljuje dječja knjiga i građa za medioteke knjižnica koje imaju tehničke mogućnosti njihova korištenja. Knjižničari, članovi Povjerenstva, ukazivali su da otkup kao način popunjavanja knjižnih fondova narodnih knjižnica nije najbolje rješenje jer se na neki način stvaraju knjižnice s jednoličnim fondovima, a smatraju i da bi trebalo poštovati regionalne različitosti. Ministarstvo je ostalo pri stajalištu da je otkup potreban zbog potpore i promidžbe nakladništva Republike Hrvatske. Ukazujući na ulogu narodnih knjižnica nastojalo se otkupiti što više naslova potrebnih za sve tipove korisnika navedenih knjižnica.

Prije nego što rezimiramo mišljenja i stavove knjižničara o otkupu knjiga, u nastavku rada navest ćemo način distribucije i raspodjele otkupljenih knjiga od

25 Članovi Kulturnog vijeća za knjižnu, nakladničku i knjižarsku djelatnost [citirano: 2017-0408]. Dostupno na http://www.min-kulture.hr/default.aspx?id=191 . 
izdavača do knjižnica. Kako smo već naveli, GISKO je od 1998. godine, kao matična knjižnica Osječko-baranjske županije, vršio raspodjelu otkupljenih knjiga pri Ministarstvu kulture narodnim knjižnicama na tom području, na kojem djeluje devet narodnih knjižnica, i to sedam gradskih i dvije općinske. Na prijedlog Povjerenstva za nakladništvo i otkup knjiga otkupljivano je 50, 100, 150 i $250^{26}$ primjeraka pojedinih naslova, što znači da su u GISKO od ukupno 50 otkupljenih primjeraka stizala 4 primjerka, od ukupno 100 primjeraka - njih 7, od ukupno 150 primjeraka - 10 primjeraka, a od ukupno 250 primjeraka - 11 primjeraka određenoga naslova. Pri raspodjeli otkupljenih primjeraka vodilo se računa da knjižnice dobiju u fond knjige prema svom statusu, broju stanovnika i korisnika te veličini fonda, što je vidljivo i iz priložene tablice (vidi tablicu 2). Kriteriji i način raspodjele otkupljenih knjiga dogovoreni su na sastanku 28. svibnja 1998. godine u Osijeku, u nazočnosti ravnatelja i stručnih djelatnika svih devet narodnih knjižnica s područja Osječko-baranjske županije. Tako od četiri primjerka po jedan dobivaju Osijek, Đakovo, Beli Manastir i Našice; od sedam primjeraka po jedan su dobivali Osijek, Đakovo, Beli Manastir, Našice, Valpovo, Donji Miholjac i Belišće; od deset primjeraka Osijek je dobivao dva, a ostali po jedan primjerak; od jedanaest primjeraka po dva su dobivali Osijek i Đakovo, a ostali po jedan primjerak.

Tablica 2. Mreža narodnih knjižnica Osječko-baranjske županije - stanje 2001. g. ${ }^{27}$

\begin{tabular}{|l|c|c|c|c|c|c|}
\hline Knjižnica & Grad/općina & $\begin{array}{c}\text { Br. } \\
\text { stanovnika }\end{array}$ & $\begin{array}{c}\text { Ukupan } \\
\text { fond }\end{array}$ & Br. članova & Odrasli & Djeca \\
\hline Osijek & Grad & 129.792 & 317.002 & 10.067 & 6.576 & 3.421 \\
\hline Đakovo & Grad & 29.493 & 52.147 & 2.810 & 2.181 & 629 \\
\hline Beli Manastir & Grad & 13.108 & 46.647 & 697 & 417 & 280 \\
\hline Našice & Grad & 17.236 & 20.890 & 1.090 & 649 & 441 \\
\hline Valpovo & Grad & 12.607 & 19.220 & 658 & 396 & 262 \\
\hline Donji Miholjac & Grad & 10.650 & 11.714 & 521 & 388 & 133 \\
\hline Belišće & Grad & 12.456 & 15.990 & 729 & 483 & 246 \\
\hline Čepin & Općina & 11.530 & 15.023 & 869 & 454 & 415 \\
\hline Đurđenovac & Općina & 9.293 & 8.364 & 229 & 140 & 89 \\
\hline
\end{tabular}

26 Danas se knjige otkupljuju u količinama od 20, 80, 85, 175 i 255 primjeraka. Usp. Javni poziv za otkup knjiga i časopisa za narodne knjižnice [citirano 2017-04-08]. Dostupno na http://www. min-kulture.hr/default.aspx?id=11744.

27 Podatke je ustupila Razvojna matična služba Gradske i sveučilišne knjižnice Osijek. Uspoređujući prijašnje podatke sa stanjem u 2014. godini, vidljivo je opadanje broja stanovnika u gradovima i općinama, a u skladu s time uglavnom u svim mjestima dolazi i do smanjivanja broja korisnika. Ukupan fond u svim knjižnicama, razumljivo je, raste. 
Tablica 3. Mreža narodnih knjižnica Osječko-baranjske županije - stanje 2014. godine $^{28}$

\begin{tabular}{|l|c|c|c|c|c|c|}
\hline Knjižnica & Grad/općina & $\begin{array}{c}\text { Br. } \\
\text { stanovnika }\end{array}$ & $\begin{array}{c}\text { Ukupan } \\
\text { fond }\end{array}$ & Br. članova & Odrasli & Djeca \\
\hline Osijek & Grad & 108.048 & 491.024 & 13.445 & 11.486 & 1.959 \\
\hline Đakovo & Grad & 27.745 & 85.129 & 2.711 & 1.991 & 720 \\
\hline Beli Manastir & Grad & 10.068 & 50.365 & 1.039 & 445 & 594 \\
\hline Našice & Grad & 16.224 & 54.512 & 631 & 329 & 302 \\
\hline Valpovo & Grad & 11.563 & 39.099 & 491 & 315 & 176 \\
\hline Donji Miholjac & Grad & 9.491 & 35.306 & 442 & 272 & 170 \\
\hline Belišće & Grad & 10.825 & 35.550 & 516 & 358 & 158 \\
\hline Čepin & Općina & 11.599 & 26.443 & 508 & 284 & 224 \\
\hline Đurđenovac & Općina & 6.750 & 14.130 & 273 & 122 & 151 \\
\hline
\end{tabular}

Od 2000. godine Matične knjižnice više ne distribuiraju otkupljene naslove, nego svaka knjižnica izravno od izdavača dobiva samo svoje primjerke prema adresaru koji nakladnici dobivaju iz Ministarstva kulture. Na takav način popunjavanja fondova narodnih knjižnica knjižničari su iskazali opravdane prigovore koji su se sveli na nekoliko osnovnih problema, a koji uglavnom nisu otklonjeni sve do danas.

Raspodjela otkupljenih naslova nije uključivala sve knjižnice u Hrvatskoj. Velik broj narodnih knjižnica u manjim mjestima, kao i ogranci u gradovima i općinama, većinu naslova, čak i beletristike, nabavljaju u samo jednom primjerku i po tome su vjerojatno potpuno izostavljene raspačavanjem otkupa. Narodne knjižnice, među kojima je i GISKO, uglavnom nabavljaju više primjeraka pojedinih naslova. Iako imaju potrebe za tim naslovima, oni često zbog nedostatka informacija (koje su sad dostupne na mrežnim stranicama Ministarstva ${ }^{29}$ ), ali i zakasnjelog otkupa, postaju prekobrojni u slučajevima kada je knjižnica kupnjom već osigurala taj naslov procijenivši ga aktualnim ili prijeko potrebnim. Uz beletrističke naslove, čest je to slučaj i pri kontinuiranoj nabavi referentne građe, poput enciklopedijskih izdanja ${ }^{30}$ koja su uglavnom u višoj cjenovnoj kategoriji. Time su za nabavu suvišnog primjerka nepotrebno utrošena sredstva koja su se mogla utrošiti za kupnju nekog drugog, potrebnijeg, naslova. Na temelju pravodobne obavijesti

\footnotetext{
28 Isto.

29 Otkup knjiga - pregled sa stanjem u 2013. g. [citirano: 2017-04-08]. Dostupno na http://www. min-kulture.hr/default.aspx?id=8912.

30 Knjižnica primjerice ima tri sveska enciklopedijskog izdanja određenog naslova koja su izašla i već ih posjeduje te želi nabaviti četvrti svezak. Zbog kašnjenja informacije hoće li Ministarstvo kulture otkupiti taj svezak, nabavi ga kupnjom. Kada stigne otkupom, on postaje prekobrojan i često taj drugi primjerak enciklopedijskog izdanja ostaje nekompletiran.
} 
o tome što je prihvaćeno za otkup knjižnice bi mogle planski izostaviti iz redovite kupnje naslove za koje znaju da će ih dobiti otkupom.

Česti su prigovori bili upućivani i izdavačima. Prema popisima Ministarstva nemoguće je provjeriti jesu li nakladnici točno raspačali sve otkupljene naslove, jesu li neki naslovi pogreškom ili nemarom izostavljeni i sl. U tehničke i organizacijske manjkavosti tako provedena otkupa i njegova raspačavanja pripada i neuredna, manjkava ili nepostojeća dokumentacija koju nakladnici šalju, odnosno ne šalju uz pakete knjiga. Često ne postoji nikakav popis naslova, odnosno dostavnica, otpremnica ili neki sličan dokument, nisu napisane cijene potrebne za uredno vođenje inventarnih knjiga ili se one razlikuju od onih dobivenih od Ministarstva. Ministarstvo je prihvatilo neke od navedenih prigovora knjižničara, ali je otkup nastavljen s neznatnim izmjenama, i dalje uz brojne nedostatke. Nakon uključivanja knjižničara u Povjerenstvo, knjižnicama su slani popisi otkupljenih naslova koji su uglavnom kasnili, ali su barem donekle omogućili uvid u otkupljene naslove. Na preporuku Ministarstva kulture nakladnici su nastojali biti uredniji u dostavljanju knjiga, ali neodgovarajući broj primjeraka (manji ili čak veći od utvrđenog) bio je razlog nepotrebnog dopisivanja knjižnica s mjerodavnim uredom u Ministarstvu o stvarnom broju primjeraka koji je trebao biti dostavljen. Unatoč popisima, pregled otkupljenih naslova bio je, a i dalje jest, otežan; da bi se došlo do stvarnoga stanja, potrebno je pratiti nekoliko popisa unatrag, a katkad su primjerci novih naslova stizali prije popisa.

Prigovora knjižničara na kvalitetu odabira naslova pristiglih otkupom sve je manje, a uz malo truda moguća su i određena tehnička i organizacijska poboljšanja. Naime početkom 2014. godine iz Službe za knjižničnu djelatnost i promidžbu knjige Ministarstva kulture RH pristigla je dopuna dopisa vezanog uz izvješća kojim se traži uvid u postupanje s otkupljenom knjižničnom građom. Kako se izvješća knjižnica o zaprimljenim knjigama pristiglim otkupom Ministarstva kulture zbog korištenja različitih softvera, vođenja inventarnih knjiga i pristizanja otkupljenih knjiga u drugom kalendarskom razdoblju podatkovno ne podudaraju s brojčanim podacima Ministarstva, stručne službe Ministarstva izradile su $E x$ cel-tablice s popisima otkupljenih naslova u 2013. godini za svaku pojedinu knjižnicu. Tablica s popisima za 2013. godinu u GISKO je pristigla u 2014. godini, što je samo po sebi loše i problematično zbog retroaktivnog unosa traženih podataka (inventarni broj i broj primjeraka) za cijelu proteklu godinu, ali su uočene i prednosti takva izvještavanja. Uz ujednačenost i preglednost tablica, što je važno kako za Ministarstvo tako i za djelatnike i službe zadužene za otkupljenu građu, važno je naglasiti bolju kontrolu nad izdavačima, ali i kvalitetniju tehničku pretraživost priloženih tablica, što uvelike štedi vrijeme i snalaženje u priloženim popisima. Ako bi se višegodišnji problem pristizanja popisa riješio tako da knjižnice dobiju nove Excel-tablice u onom trenutku kada Ministarstvo odobri otkup, ne treba posebno isticati ostvarivanje znatnih ušteda boljim gospodarenjem namjenskim 
sredstvima knjižnica za nabavu knjižne i neknjižne građe, a time i omogućavanje boljih izgradnji zbirki. Tablice s naslovima otkupljene krađe koje knjižnice trebaju popunjavati inventarnim brojevima treba slati, ako već ne prije, barem po objavi popisa, čime bi se izbjegao dugotrajan retroaktivni unos podataka.

Navedenim je potvrđena činjenica da samo analiza fonda neke knjižnice i analiza strukture i potreba njezinih korisnika te pomno i stručno provođenje nabave mogu rezultirati pravilnim odabirom prinova. Kada govorimo o nedostatku sredstava, potrebno je naglasiti da je nekim manjim knjižnicama obuhvaćenim otkupom to jedini izvor popunjavanja knjižnih zbirki.

\subsection{Prikaz i analiza otkupa Ministarstva kulture u GISKO-u u raz- doblju 1998. - 2013.}

Kada je riječ o broju knjiga koje su pribavljene u jednoj godini tim načinom, treba spomenuti da se podaci odnose isključivo na primljene i obrađene knjige $u$ tekućoj godini. Budući da su paketi s otkupom knjiga često kasnili, mnoge su knjige otkupljene, primjerice, u 1999. godini pristigle u knjižnicu 2000. godine i tako će u analizi ovoga rada biti relevantni podaci za 2000. godinu. No držimo da takvi pomaci ne utječu na zaključke dobivene ovom analizom. Izvore podataka predstavljale su nam knjige inventara ${ }^{31}$ GISKO-a. Knjižna građa u GISKO-u obrađena je i smještena na policama prema svome sadržaju. Sadržajno signiranje vrši se prema Univerzalnoj decimalnoj klasifikaciji. Uz potrebne podatke za inventariziranje knjiga unosi se i signatura, koja je predstavljala ključni element ove analize. Prema njoj smo svaki prinovljeni naslov otkupom svrstali u pripadajuću UDK-skupinu s brojem primjeraka te odredili kojoj je skupini korisnika namijenjen. Posebno su analizirani podaci o knjigama namijenjenima odraslim korisnicima, a posebno o onima namijenjenima djeci. Na kraju smo iskazali statističke podatke o načinu nabave u GISKO-u kako bismo utvrdili ukupan udio otkupa u izgradnji fonda.

\section{Knjige za odrasle}

Knjige za odrasle analizirali smo prema dvjema osnovnim grupama knjižnog fonda u GISKO-u. U prvoj grupi zastupljeni su naslovi s brojem primjeraka iz beletristike/književnosti, uključujući esejistiku i memoare domaće i strane književnosti, a u drugoj stručna i popularno-znanstvena te priručna ili referentna literatura.

\section{Analiza podataka knjiga za odrasle}

Tablica 4 prikazuje omjer ukupnog broja naslova i broja primjeraka stručne i znanstveno-popularne literature prema UDK-skupinama od 0 do 9 , uključujući

31 Knjiga inventara u knjižnici stvaran je dokaz o tome da je određena građa stigla u knjižnicu te da je uključena u njezin fond. 
teoriju i kritiku iz grupe 8, s ukupnim brojem naslova i primjeraka domaće i strane beletristike/književnosti po godinama.

Tablica 4. Omjer znanstvene i popularno-znanstvene literature te književnosti/beletristike - naslovi i broj primjeraka

\begin{tabular}{|l|l|l|l|l|l|l|l|l|l|l|l|l|l|l|l|l|}
\hline Naslovi & 1998. & 1999. & 2000. & 2001. & 2002. & 2003. & 2004. & 2005. & 2006. & 2007. & 2008. & 2009. & 2010. & 2011. & 2012. & 2013. \\
\hline Ostalo & 161 & 594 & 156 & 806 & 445 & 811 & 699 & 728 & 581 & 1244 & 302 & 599 & 464 & 735 & 463 & 566 \\
\hline Književnost & 90 & 541 & 128 & 700 & 532 & 694 & 694 & 607 & 422 & 765 & 260 & 484 & 318 & 545 & 412 & 456 \\
\hline Ukupno & 290 & 1135 & 284 & 1506 & 977 & 1505 & 1393 & 1335 & 1003 & 2009 & 562 & 1083 & 782 & 1280 & 875 & 1022 \\
\hline
\end{tabular}

\begin{tabular}{|l|l|l|l|l|l|l|l|l|l|l|l|l|l|l|l|l|}
\hline \multicolumn{1}{|l|}{ Primjerci } \\
\hline Ostalo & 175 & 747 & 207 & 1402 & 627 & 881 & 699 & 765 & 581 & 1244 & 302 & 599 & 464 & 735 & 463 & 566 \\
\hline Književnost & 115 & 765 & 166 & 1782 & 826 & 1110 & 694 & 672 & 422 & 784 & 260 & 505 & 322 & 545 & 412 & 456 \\
\hline Ukupno & 290 & 1512 & 373 & 2884 & 1453 & 1991 & 1393 & 1437 & 1003 & 2028 & 562 & 1104 & 786 & 1280 & 875 & 1022 \\
\hline
\end{tabular}

U 1998. godini pristiglo je više naslova iz područja znanosti $(64,1 \%)$ u odnosu na književnost (35,9\%), ali u većem broju primjeraka (39,7\%), dok je iz područja znanosti broj primjeraka u odnosu na broj naslova manji (60,3\%). Dok je 2002. godine pristiglo više naslova iz književnosti $(54,5 \%)$ i u većem broju primjeraka $(56,8 \%)$, a znanosti $(45,5 \%)$ u 43,2 \% primjeraka, 1999. i 2001. godine taj je omjer gotovo podjednak.

\section{Književnost/beletristika}

Tablica 5 prikazuje zastupljenost ukupnog broja naslova/primjeraka domaće književnosti u odnosu na stranu.

Tablica 5. Književnost/beletristika - naslovi i broj primjeraka

\begin{tabular}{|l|c|c|c|c|c|c|c|c|c|c|c|c|c|c|c|c|}
\hline Naslovi & 1998. & 1999. & 2000. & 2001. & 2002. & 2003. & 2004. & 2005. & 2006. & 2007. & 2008. & 2009. & 2010. & 2011. & 2012. & 2013. \\
\hline Strana & 6 & 141 & 45 & 257 & 168 & 226 & 230 & 212 & 164 & 321 & 100 & 188 & 137 & 243 & 195 & 225 \\
\hline Domaća & 80 & 349 & 79 & 402 & 330 & 428 & 464 & 395 & 258 & 444 & 160 & 296 & 181 & 302 & 217 & 231 \\
\hline Ukupno & 86 & 490 & 124 & 659 & 498 & 654 & 694 & 607 & 422 & 765 & 260 & 484 & 318 & 545 & 412 & 456 \\
\hline
\end{tabular}

\begin{tabular}{|l|c|c|c|c|c|c|c|c|c|c|c|c|c|c|c|c|}
\hline \multicolumn{10}{|l|}{ Primjerci } \\
\hline Strana & 10 & 186 & 53 & 578 & 237 & 306 & 230 & 230 & 164 & 335 & 100 & 191 & 137 & 243 & 195 & 225 \\
\hline Domaća & 100 & 510 & 107 & 807 & 531 & 804 & 464 & 442 & 258 & 449 & 160 & 314 & 185 & 302 & 217 & 231 \\
\hline Ukupno & 110 & 696 & 160 & 1385 & 768 & 1110 & 694 & 672 & 422 & 784 & 260 & 505 & 322 & 545 & 412 & 456 \\
\hline
\end{tabular}


Domaća je književnost tijekom promatranoga razdoblja najviše zastupljena, što nije iznenađujuće budući da u otkupu domaći autori imaju prednost. Najmanje naslova strane književnosti, deset primjeraka, otkupljeno je 1998. godine, a najviše 2001. godine, 578 primjeraka. U 2001. godini, gledano brojčano, otkupljeno je najviše naslova (402) u 807 primjeraka domaće književnosti i 257 naslova u 578 primjeraka strane. U 2000. i 1998. godini otkupljeno je najmanje naslova iz domaće književnosti (79 i 80) u 100 i 107 primjeraka.

\section{Domaća književnost}

Književnost sadržajno grupiramo prema književnim rodovima: poezija, drama, roman/pripovijetka, esej, pisma, satira, viševrsna (više rodova u knj. jedinici), memoare i drugo. Tablice 6 i 6a prikazuju domaću književnost i zastupljenost naslova/primjerka prema navedenim rodovima.

Tablica 6. Domaća književnost - naslovi

\begin{tabular}{|l|c|c|c|c|c|c|c|c|c|c|c|c|c|c|c|c|}
\hline Naslovi & 1998. & 1999. & 2000. & 2001. & 2002. & 2003. & 2004. & 2005. & 2006. & 2007. & 2008. & 2009. & 2010. & 2011. & 2012. & 2013. \\
\hline Poezija & 32 & 116 & 28 & 132 & 103 & 122 & 134 & 135 & 73 & 182 & 52 & 97 & 54 & 92 & 54 & 54 \\
\hline Drama & 0 & 11 & 1 & 19 & 20 & 18 & 38 & 11 & 14 & 22 & 7 & 14 & 12 & 13 & 20 & 10 \\
\hline $\begin{array}{l}\text { Roman/ } \\
\text { Pripovijetka }\end{array}$ & 22 & 113 & 29 & 145 & 148 & 168 & 190 & 133 & 84 & 148 & 65 & 107 & 69 & 119 & 62 & 109 \\
\hline Esej & 1 & 20 & 3 & 12 & 4 & 18 & 12 & 14 & 18 & 19 & 9 & 15 & 6 & 7 & 7 & 12 \\
\hline Pisma & 0 & 0 & 0 & 2 & 2 & 3 & 6 & 0 & 5 & 0 & 1 & 1 & 1 & 1 & 0 & 4 \\
\hline Satira & 0 & 0 & 1 & 1 & 0 & 3 & 0 & 0 & 2 & 2 & 0 & 0 & 0 & 1 & 0 & 0 \\
\hline Viševrsna & 19 & 47 & 5 & 53 & 17 & 75 & 60 & 82 & 41 & 57 & 15 & 52 & 29 & 46 & 65 & 27 \\
\hline Memoari & 6 & 42 & 12 & 38 & 36 & 21 & 24 & 20 & 21 & 14 & 11 & 10 & 10 & 23 & 9 & 15 \\
\hline Ukupno & 80 & 349 & 79 & 402 & 330 & 428 & 464 & 395 & 258 & 444 & 160 & 296 & 181 & 302 & 217 & 231 \\
\hline
\end{tabular}

Tablica 6a. Domaća književnost - broj primjeraka

\begin{tabular}{|l|c|c|c|c|c|c|c|c|c|c|c|c|c|c|c|c|}
\hline Primjerci & 1998. & 1999. & 2000. & 2001. & 2002. & 2003. & 2004. & 2005. & 2006. & 2007. & 2008. & 2009. & 2010. & 2011. & 2012. & 2013. \\
\hline Poezija & 46 & 164 & 36 & 240 & 149 & 221 & 134 & 150 & 73 & 182 & 52 & 97 & 58 & 92 & 54 & 54 \\
\hline Drama & 0 & 14 & 1 & 44 & 35 & 33 & 38 & 13 & 14 & 22 & 7 & 24 & 12 & 13 & 20 & 10 \\
\hline $\begin{array}{l}\text { Roman/Pri- } \\
\text { povijetka }\end{array}$ & 26 & 164 & 39 & 300 & 239 & 289 & 190 & 153 & 84 & 148 & 65 & 110 & 69 & 119 & 62 & 109 \\
\hline Esej & 1 & 20 & 3 & 28 & 7 & 48 & 12 & 14 & 18 & 19 & 9 & 15 & 6 & 7 & 7 & 12 \\
\hline Pisma & 0 & 0 & 0 & 3 & 4 & 20 & 6 & 0 & 5 & 0 & 1 & 3 & 1 & 1 & 0 & 4 \\
\hline Satira & 0 & 0 & 1 & 1 & 0 & 3 & 0 & 0 & 2 & 2 & 0 & 0 & 0 & 1 & 0 & 0 \\
\hline
\end{tabular}




\begin{tabular}{|l|c|c|c|c|c|c|c|c|c|c|c|c|c|c|c|c|}
\hline Primjerci & 1998. & 1999. & 2000. & 2001. & 2002. & 2003. & 2004. & 2005. & 2006. & 2007. & 2008. & 2009. & 2010. & 2011. & 2012. & 2013. \\
\hline Viševrsna & 21 & 91 & 7 & 113 & 32 & 156 & 60 & 84 & 41 & 61 & 15 & 55 & 29 & 46 & 65 & 27 \\
\hline Memoari & 6 & 57 & 20 & 78 & 65 & 34 & 24 & 28 & 21 & 15 & 11 & 10 & 10 & 23 & 9 & 15 \\
\hline Ukupno & 100 & 510 & 107 & 807 & 531 & 804 & 464 & 442 & 258 & 449 & 160 & 314 & 185 & 302 & 217 & 231 \\
\hline
\end{tabular}

Predstavljeni podaci pokazuju nam da su romani/pripovijetke bili najzastupljeniji 2002., u odnosu na druge rodove brojčano izraženo - 148 naslova u 239 primjeraka, a zatim u 2001. godini - 145 naslova u 300 primjerka. Ukupno gledajući, 2001. godina u odnosu na sve rodove prednjači s otkupljena 402 naslova u 807 primjeraka. Tijekom promatranoga razdoblja najmanje su zastupljeni eseji, pisma i satira.

\section{Strana književnost}

Strana književnost grupirana je prema pojedinim nacionalnim književnostima. Tablice 7 i 7 a prikazuju zastupljenost određene nacionalne književnosti u ukupnom broju naslova/primjerka strane književnosti.

Tablica 7. Strana književnost - naslovi

\begin{tabular}{|l|c|c|c|c|c|c|c|c|c|c|c|c|c|c|c|c|}
\hline Naslovi & 1998. & 1999. & 2000. & 2001. & 2002. & 2003. & 2004. & 2005. & 2006. & 2007. & 2008. & 2009. & 2010. & 2011. & 2012. & 2013. \\
\hline Engleska & 1 & 18 & 12 & 55 & 46 & 46 & 35 & 37 & 29 & 42 & 13 & 16 & 21 & 40 & 43 & 40 \\
\hline Američka & 2 & 24 & 11 & 47 & 27 & 32 & 25 & 19 & 19 & 16 & 9 & 24 & 13 & 27 & 15 & 16 \\
\hline Njemačka & 1 & 15 & 2 & 31 & 21 & 28 & 25 & 39 & 21 & 16 & 19 & 17 & 9 & 27 & 24 & 23 \\
\hline $\begin{array}{l}\text { Ostale germ. } \\
\text { knjiž. }\end{array}$ & 0 & 6 & 1 & 3 & 4 & 22 & 19 & 21 & 5 & 52 & 4 & 20 & 13 & 9 & 10 & 11 \\
\hline Francuska & 1 & 20 & 5 & 25 & 20 & 6 & 2 & 8 & 7 & 12 & 2 & 5 & 2 & 8 & 6 & 5 \\
\hline Talijanska & 0 & 10 & 2 & 15 & 5 & 2 & 0 & 0 & 0 & 0 & 1 & 1 & 0 & 0 & 1 & 1 \\
\hline Španjolska & 1 & 4 & 1 & 8 & 17 & 6 & 9 & 4 & 4 & 10 & 3 & 3 & 6 & 6 & 3 & 8 \\
\hline $\begin{array}{l}\text { Španjol- } \\
\text { sko-američka }\end{array}$ & 0 & 5 & 3 & 19 & 0 & 2 & 12 & 0 & 1 & 3 & 4 & 15 & 1 & 5 & 2 & 9 \\
\hline $\begin{array}{l}\text { Brazilska i } \\
\text { portugalska }\end{array}$ & 0 & 1 & 1 & 5 & 4 & 0 & 9 & 8 & 4 & 30 & 10 & 13 & 9 & 15 & 9 & 8 \\
\hline Latinska & 0 & 5 & 1 & 1 & 0 & 31 & 45 & 30 & 25 & 53 & 14 & 21 & 21 & 38 & 19 & 40 \\
\hline Starogrčka & 0 & 3 & 0 & 0 & 0 & 0 & 2 & 8 & 6 & 14 & 3 & 11 & 9 & 10 & 6 & 12 \\
\hline Ruska & 0 & 8 & 0 & 7 & 7 & 14 & 17 & 14 & 5 & 13 & 4 & 13 & 6 & 17 & 11 & 10 \\
\hline Poljska & 0 & 4 & 1 & 4 & 1 & 7 & 4 & 0 & 11 & 14 & 0 & 1 & 0 & 6 & 7 & 5 \\
\hline $\begin{array}{l}\text { Češka i } \\
\text { slovačka }\end{array}$ & 0 & 5 & 1 & 11 & 3 & 1 & 2 & 0 & 0 & 0 & 1 & 3 & 1 & 2 & 0 & 0 \\
\hline
\end{tabular}




\begin{tabular}{|l|c|c|c|c|c|c|c|c|c|c|c|c|c|c|c|c|}
\hline Naslovi & 1998. & 1999. & 2000. & 2001. & 2002. & 2003. & 2004. & 2005. & 2006. & 2007. & 2008. & 2009. & 2010. & 2011. & 2012. & 2013. \\
\hline Srpska & 0 & 1 & 0 & 3 & 4 & 6 & 5 & 1 & 5 & 12 & 2 & 3 & 10 & 10 & 11 & 7 \\
\hline Slovenska & 0 & 1 & 0 & 1 & 1 & 6 & 3 & 3 & 2 & 6 & 1 & 2 & 2 & 2 & 6 & 2 \\
\hline $\begin{array}{l}\text { Bosansko-her- } \\
\text { cegovačka }\end{array}$ & 0 & 5 & 2 & 6 & 2 & 2 & 0 & 0 & 5 & 3 & 2 & 2 & 1 & 6 & 3 & 8 \\
\hline $\begin{array}{l}\text { Istočne, } \\
\text { afričke, ostale } \\
\text { knjiž. }\end{array}$ & 0 & 6 & 2 & 16 & 6 & 17 & 16 & 20 & 15 & 25 & 8 & 18 & 13 & 15 & 19 & 20 \\
\hline Ukupno & 6 & 141 & 45 & 257 & 168 & 226 & 230 & 212 & 164 & 321 & 100 & 188 & 137 & 243 & 195 & 225 \\
\hline
\end{tabular}

Tablica 7a. Strana književnost - broj primjeraka

\begin{tabular}{|l|l|l|l|l|l|l|l|l|l|l|l|l|l|l|l|l|}
\hline Primjerci & 1998. & 1999. & 2000. & 2001. & 2002. & 2003. & 2004. & 2005. & 2006. & 2007. & 2008. & 2009. & 2010. & 2011. & 2012. & 2013. \\
\hline
\end{tabular}

\begin{tabular}{|c|c|c|c|c|c|c|c|c|c|c|c|c|c|c|c|c|}
\hline Engleska & 3 & 24 & 16 & 127 & 66 & 55 & 35 & 43 & 29 & 42 & 13 & 16 & 21 & 40 & 43 & 40 \\
\hline Američka & 4 & 30 & 11 & 92 & 35 & 44 & 25 & 19 & 19 & 20 & 9 & 24 & 13 & 27 & 15 & 16 \\
\hline Njemačka & 1 & 20 & 3 & 68 & 29 & 38 & 25 & 39 & 21 & 18 & 19 & 17 & 9 & 27 & 24 & 23 \\
\hline $\begin{array}{l}\text { Ostale } \\
\text { germ. } \\
\text { knjiž. }\end{array}$ & 0 & 9 & 1 & 9 & 7 & 30 & 19 & 21 & 5 & 52 & 4 & 22 & 13 & 9 & 10 & 11 \\
\hline Francuska & 1 & 30 & 6 & 61 & 30 & 9 & 2 & 8 & 7 & 12 & 2 & 5 & 2 & 8 & 6 & 5 \\
\hline Talijanska & 0 & 12 & 3 & 37 & 10 & 4 & 0 & 0 & 0 & 0 & 1 & 1 & 0 & 0 & 1 & 1 \\
\hline Španjolska & 1 & 4 & 1 & 11 & 21 & 9 & 9 & 4 & 4 & 10 & 3 & 3 & 6 & 6 & 3 & 8 \\
\hline $\begin{array}{l}\text { Španjol- } \\
\text { sko-ame- } \\
\text { rička }\end{array}$ & 0 & 6 & 3 & 44 & 0 & 3 & 12 & 0 & 1 & 3 & 4 & 15 & 1 & 5 & 2 & 9 \\
\hline $\begin{array}{l}\text { Brazilska i } \\
\text { portugal- } \\
\text { ska }\end{array}$ & 0 & 1 & 1 & 12 & 6 & 0 & 9 & 8 & 4 & 35 & 10 & 13 & 9 & 15 & 9 & 8 \\
\hline Latinska & 0 & 6 & 1 & 1 & 0 & 46 & 45 & 40 & 25 & 53 & 14 & 21 & 21 & 38 & 19 & 40 \\
\hline Starogrčka & 0 & 4 & 0 & 0 & 0 & 0 & 2 & 8 & 6 & 14 & 3 & 11 & 9 & 10 & 6 & 12 \\
\hline Ruska & 0 & 8 & 0 & 17 & 10 & 22 & 17 & 14 & 5 & 13 & 4 & 13 & 6 & 17 & 11 & 10 \\
\hline Poljska & 0 & 6 & 2 & 9 & 1 & 7 & 4 & 0 & 11 & 14 & 0 & 1 & 0 & 6 & 7 & 5 \\
\hline $\begin{array}{l}\text { Češka i } \\
\text { slovačka }\end{array}$ & 0 & 8 & 1 & 30 & 6 & 1 & 2 & 0 & 0 & 0 & 1 & 3 & 1 & 2 & 0 & 0 \\
\hline Srpska & 0 & 1 & 0 & 7 & 4 & 6 & 5 & 1 & 5 & 15 & 2 & 3 & 10 & 10 & 11 & 7 \\
\hline Slovenska & 0 & 1 & 0 & 2 & 1 & 8 & 3 & 3 & 2 & 6 & 1 & 2 & 2 & 2 & 6 & 2 \\
\hline
\end{tabular}




\begin{tabular}{|l|c|c|c|c|c|c|c|c|c|c|c|c|c|c|c|c|}
\hline Primjerci & 1998. & 1999. & 2000. & 2001. & 2002. & 2003. & 2004. & 2005. & 2006. & 2007. & 2008. & 2009. & 2010. & 2011. & 2012. & 2013. \\
\hline $\begin{array}{l}\text { Bosan- } \\
\text { sko-herce- } \\
\text { govačka }\end{array}$ & 0 & 7 & 2 & 11 & 2 & 2 & 0 & 0 & 5 & 3 & 2 & 2 & 1 & 6 & 3 & 8 \\
\hline $\begin{array}{l}\text { Istočne, } \\
\text { afričke, } \\
\text { ostale } \\
\text { knjiž. }\end{array}$ & 0 & 9 & 2 & 40 & 9 & 22 & 16 & 22 & 12 & 25 & 8 & 18 & 13 & 15 & 19 & 20 \\
\hline Ukupno & 10 & 186 & 53 & 578 & 237 & 306 & 230 & 230 & 164 & 335 & 100 & 191 & 137 & 243 & 195 & 225 \\
\hline
\end{tabular}

U 1998. godini najzastupljenija je bila američka književnost, s dva naslova u četiri primjerka. Ukupno je te godine pristiglo samo šest naslova u deset primjeraka, što je ujedno i najmanji broj otkupljenih naslova tijekom istraživanoga razdoblja. Godine 2001. pristiglo je najviše naslova/primjerka strane književnosti (257 naslova u 578 primjerka), kada je engleska književnost najzastupljenija prema broju naslova i primjeraka (55 naslova u 127 primjeraka). Ostatak istraživanog razdoblja daje podjednak broj otkupljenih primjeraka koji se proteže u rasponu od stotinu primjeraka u 2008. godini do maksimalnih 306 i 335 primjeraka u 2003., odnosno 2007. godini.

\section{Zavičajna zbirka}

Tablice 8 i 8a predstavljaju udio naslova/primjeraka (koji prema sadržajnim kriterijima pripadaju zavičajnoj zbirci) u ukupno pristiglom otkupu prema UDK-grupama.

Tablica 8. Zavičajna zbirka - naslovi

\begin{tabular}{|c|c|c|c|c|c|c|c|c|c|c|c|c|c|c|c|c|}
\hline Naslovi & 1998. & 1999. & 2000. & 2001. & 2002. & 2003. & 2004. & 2005. & 2006. & 2007. & 2008. & 2009. & 2010. & 2011. & 2012. & 2013. \\
\hline 0 & 0 & 0 & 1 & 1 & 0 & 1 & 0 & 0 & 0 & 0 & 0 & 0 & 0 & 0 & 0 & 0 \\
\hline 1 & 0 & 0 & 0 & 1 & 0 & 0 & 0 & 0 & 1 & 1 & 0 & 0 & 0 & 0 & 0 & 0 \\
\hline 2 & 2 & 2 & 0 & 3 & 2 & 0 & 0 & 0 & 0 & 2 & 0 & 0 & 0 & 0 & 0 & 0 \\
\hline 3 & 1 & 2 & 2 & 2 & 1 & 1 & 0 & 0 & 1 & 4 & 0 & 0 & 1 & 0 & 2 & 0 \\
\hline 5 & 0 & 0 & 1 & 0 & 0 & 0 & 2 & 0 & 0 & 0 & 0 & 0 & 0 & 0 & 0 & 0 \\
\hline 6 & 3 & 0 & 1 & 2 & 0 & 0 & 0 & 0 & 1 & 1 & 0 & 0 & 0 & 0 & 0 & 0 \\
\hline 7 & 1 & 7 & 0 & 2 & 0 & 1 & 0 & 0 & 0 & 1 & 1 & 0 & 0 & 0 & 4 & 1 \\
\hline 8 & 0 & 10 & 4 & 26 & 8 & 2 & 5 & 5 & 2 & 16 & 3 & 2 & 0 & 2 & 3 & 9 \\
\hline 9 & 9 & 4 & 1 & 12 & 1 & 1 & 0 & 1 & 0 & 6 & 0 & 0 & 5 & 0 & 0 & 0 \\
\hline Ukupno & 16 & 25 & 10 & 49 & 12 & 6 & 7 & 6 & 5 & 31 & 4 & 2 & 6 & 2 & 9 & 10 \\
\hline
\end{tabular}


Tablica 8a. Zavičajna zbirka - broj primjeraka

\begin{tabular}{|c|c|c|c|c|c|c|c|c|c|c|c|c|c|c|c|c|}
\hline Primjerci & 1998. & 1999. & 2000. & 2001. & 2002. & 2003. & 2004. & 2005. & 2006. & 2007. & 2008. & 2009. & 2010. & 2011. & 2012. & 2013. \\
\hline 0 & 0 & 0 & 1 & 1 & 0 & 1 & 0 & 0 & 0 & 0 & 0 & 0 & 0 & 0 & 0 & 0 \\
\hline 1 & 0 & 0 & 0 & 2 & 0 & 0 & 0 & 0 & 1 & 1 & 0 & 0 & 0 & 0 & 0 & 0 \\
\hline 2 & 4 & 2 & 0 & 5 & 3 & 0 & 0 & 0 & 0 & 2 & 0 & 0 & 0 & 0 & 0 & 0 \\
\hline 3 & 1 & 2 & 2 & 2 & 1 & 1 & 0 & 0 & 1 & 4 & 0 & 0 & 1 & 0 & 2 & 0 \\
\hline 5 & 0 & 0 & 2 & 0 & 0 & 0 & 2 & 0 & 0 & 0 & 0 & 0 & 0 & 0 & 0 & 0 \\
\hline 6 & 3 & 0 & 3 & 2 & 0 & 0 & 0 & 0 & 1 & 1 & 0 & 0 & 0 & 0 & 0 & 0 \\
\hline 7 & 1 & 9 & 0 & 6 & 0 & 1 & 0 & 0 & 0 & 1 & 1 & 0 & 0 & 0 & 4 & 1 \\
\hline 8 & 0 & 15 & 5 & 55 & 23 & 2 & 5 & 5 & 2 & 16 & 3 & 2 & 5 & 2 & 3 & 9 \\
\hline 9 & 12 & 4 & 1 & 5 & 1 & 1 & 0 & 1 & 0 & 6 & 0 & 0 & 0 & 0 & 0 & 0 \\
\hline Ukupno & 21 & 32 & 14 & 78 & 28 & 6 & 7 & 6 & 5 & 31 & 4 & 2 & 6 & 2 & 9 & 10 \\
\hline
\end{tabular}

Odmah je uočljivo da je riječ o vrlo malom postotku, tako da pojedine UDK-skupine uopće nisu zastupljene. Najviše je naslova (49) u 78 primjeraka iz svih skupina pristiglo 2001. godine, dok je najmanje naslova (2) u 2 primjeraka pristiglo 2009. i 2011. godine. Najzastupljenija je skupina UDK 8 u svim godinama istraživanog razdoblja.

\section{Knjige za djecu}

Knjige za djecu podijeljene su na beletristiku i stručnu te znanstveno-popularnu literaturu. Beletristika je smještena prema sustavu oznaka: $M,{ }^{32} \mathrm{D},{ }^{33} \mathrm{O},{ }^{34} \mathrm{~N},{ }^{35}$ I. ${ }^{36} \mathrm{U}$ nastavku slijedi analiza otkupljenih naslova za djecu.

Tablica 9. Omjer beletristike (M, D, O, I, N) i stručne te znanstveno-popularne knjižne građe u ukupno pristiglom otkupu - naslovi i broj primjeraka

\begin{tabular}{|l|c|c|c|c|c|c|c|c|c|c|c|c|c|c|c|c|}
\hline Naslovi & 1998. & 1999. & 2000. & 2001. & 2002. & 2003. & 2004. & 2005. & 2006. & 2007. & 2008. & 2009. & 2010. & 2011. & 2012. & 2013. \\
\hline Beletristika & 6 & 128 & 33 & 140 & 126 & 214 & 107 & 112 & 60 & 121 & 25 & 124 & 60 & 89 & 75 & 94 \\
\hline Znanstvena & 5 & 7 & 2 & 12 & 9 & 1 & 21 & 4 & 2 & 3 & 0 & 0 & 9 & 0 & 13 & 10 \\
\hline Ukupno & 11 & 135 & 35 & 152 & 135 & 215 & 128 & 116 & 62 & 124 & 25 & 124 & 69 & 89 & 88 & 104 \\
\hline
\end{tabular}

32 Knjige namijenjene predškolskom uzrastu.

33 Knjige namijenjene školskoj djeci do 7. razreda osnovne škole.

34 Za mladež.

35 Za narodnu književnost.

36 Za igrokaze. 


\begin{tabular}{|l|c|c|c|c|c|c|c|c|c|c|c|c|c|c|c|c|}
\hline Naslovi & 1998. & 1999. & 2000. & 2001. & 2002. & 2003. & 2004. & 2005. & 2006. & 2007. & 2008. & 2009. & 2010. & 2011. & 2012. & 2013. \\
\hline Primjerci \\
\hline Beletristika & 8 & 192 & 48 & 344 & 188 & 312 & 116 & 114 & 60 & 121 & 25 & 124 & 60 & 89 & 75 & 94 \\
\hline Znanstvena & 6 & 7 & 3 & 25 & 16 & 1 & 21 & 14 & 2 & 3 & 0 & 0 & 10 & 0 & 13 & 10 \\
\hline Ukupno & 14 & 199 & 51 & 369 & 204 & 313 & 137 & 128 & 62 & 124 & 25 & 124 & 70 & 89 & 88 & 104 \\
\hline
\end{tabular}

U promatranome razdoblju vidljivo je da je najzastupljenija beletristika. Znanost je zastupljena u vrlo malom broju naslova i primjeraka. Izuzetak je 2004. godina kada je otkupljen 21 naslov u isto toliko primjeraka te 2001. godina kada je otkupljeno 12 naslova u 25 primjeraka znanstveno-popularne knjižne građe. Godine 2001. u Gradsku i sveučilišnu knjižnicu Osijek pristigao je i najveći broj otkupljenih naslova za djecu: riječ je o 369 primjeraka. Analizirajući podatke, valja naglasiti da je u novijem istraživanom razdoblju broj otkupljenih naslova istovjetan broju primjeraka.

Tablica prikazuje koliko su zastupljeni naslovi/primjerci unutar svake podjele $(\mathrm{M}, \mathrm{D}, \mathrm{O}, \mathrm{I}, \mathrm{N})$.

Tablica 10. Struktura dječje beletristike - naslovi i broj primjeraka

\begin{tabular}{|c|c|c|c|c|c|c|c|c|c|c|c|c|c|c|c|c|}
\hline Naslovi & 1998. & 1999. & 2000. & 2001. & 2002. & 2003. & 2004. & 2005. & 2006. & 2007. & 2008. & 2009. & 2010. & 2011. & 2012. & 2013. \\
\hline M & 2 & 10 & 2 & 42 & 45 & 94 & 37 & 41 & 17 & 31 & 7 & 22 & 18 & 33 & 28 & 31 \\
\hline D & 1 & 76 & 16 & 69 & 59 & 74 & 43 & 37 & 27 & 64 & 14 & 70 & 26 & 34 & 30 & 43 \\
\hline 0 & 3 & 38 & 11 & 21 & 19 & 36 & 23 & 29 & 10 & 24 & 4 & 26 & 11 & 20 & 17 & 17 \\
\hline I & 0 & 1 & 3 & 8 & 0 & 5 & 2 & 0 & 3 & 1 & 0 & 3 & 0 & 1 & 0 & 0 \\
\hline N & 0 & 3 & 1 & 0 & 3 & 5 & 2 & 5 & 3 & 1 & 0 & 3 & 5 & 1 & 0 & 3 \\
\hline Ukupno & 6 & 128 & 33 & 140 & 126 & 214 & 107 & 112 & 60 & 121 & 25 & 124 & 60 & 89 & 75 & 94 \\
\hline
\end{tabular}

\begin{tabular}{|c|c|c|c|c|c|c|c|c|c|c|c|c|c|c|c|c|}
\hline \multicolumn{2}{|c|}{ Primjerci 1998. 1999. 2000. 2001. 2002. 2003. 2004. 2005. 2006. 2007. 2008. 2009. 2010. 2011. 2012. 2013. } \\
\hline M & 2 & 12 & 2 & 118 & 79 & 103 & 40 & 42 & 17 & 31 & 7 & 22 & 18 & 33 & 28 & 31 \\
\hline D & 3 & 128 & 25 & 156 & 75 & 116 & 46 & 37 & 27 & 64 & 14 & 70 & 26 & 34 & 30 & 43 \\
\hline 0 & 3 & 49 & 17 & 52 & 30 & 72 & 26 & 30 & 10 & 24 & 4 & 26 & 11 & 20 & 17 & 17 \\
\hline I & 0 & 1 & 3 & 18 & 0 & 16 & 2 & 0 & 3 & 1 & 0 & 3 & 0 & 1 & 0 & 0 \\
\hline N & 0 & 2 & 1 & 0 & 4 & 5 & 2 & 5 & 3 & 1 & 0 & 3 & 5 & 1 & 0 & 3 \\
\hline Ukupno & 8 & 192 & 48 & 344 & 188 & 312 & 116 & 114 & 60 & 121 & 25 & 124 & 60 & 89 & 75 & 94 \\
\hline
\end{tabular}


Beletristika za djecu (D) najzastupljenija je u istraživanom razdoblju, a u najmanjem broju i postotku igrokazi (I). Godine 1999. iz skupine D pristiglo je najviše naslova (76) u 128 primjeraka, a 2001. godine najviše primjeraka (156) od 69 naslova. Navedena godina ujedno ima i najveći ukupan broj otkupljenih primjeraka (344). Što se ostalih podjela tiče, 2003. godina za skupinu M jedna je od statistički najboljih godina jer su otkupljena 94 naslova u 103 primjerka. Godina 1998. i u ovom slučaju pokazuje najmanje otkupljenih naslova, i to ukupno šest naslova i osam primjeraka.

Tablica 11. Usporedba ukupnog otkupa knjiga za odrasle i knjiga za djecu - naslovi i broj primjeraka

\begin{tabular}{|l|c|c|c|c|c|c|c|c|c|c|c|c|c|c|c|c|}
\hline Naslovi & 1998.1999 .2000$. & 2001. 2002. 2003. 2004. 2005. 2006. 2007. 2008. 2009. 2010. 2011. 2012. 2013. \\
\hline Odrasli & 251 & 1135 & 284 & 1506 & 977 & 1505 & 1393 & 1335 & 1003 & 2009 & 562 & 1083 & 782 & 1280 & 875 & 1022 \\
\hline Djeca & 11 & 135 & 35 & 152 & 135 & 215 & 128 & 116 & 62 & 124 & 25 & 124 & 69 & 89 & 88 & 104 \\
\hline Ukupno & 262 & 1270 & 319 & 1658 & 1112 & 1720 & 1521 & 1451 & 1065 & 2133 & 285 & 1207 & 851 & 1369 & 963 & 1126 \\
\hline
\end{tabular}

\begin{tabular}{|l|c|c|c|c|c|c|c|c|c|c|c|c|c|c|c|c|}
\hline \multicolumn{10}{|l|}{ Primjerci } \\
\hline Odrasli & 290 & 1512 & 373 & 2884 & 1453 & 1110 & 1393 & 1437 & 1003 & 2028 & 562 & 1104 & 786 & 1280 & 875 & 1022 \\
\hline Djeca & 14 & 199 & 51 & 369 & 204 & 313 & 137 & 128 & 62 & 124 & 25 & 124 & 70 & 89 & 88 & 104 \\
\hline Ukupno & 304 & 1711 & 424 & 3253 & 1657 & 1423 & 1521 & 1565 & 1065 & 2152 & 587 & 1228 & 856 & 1369 & 963 & 1126 \\
\hline
\end{tabular}

Najveći broj naslova fonda za odrasle (2009) u 2028 primjerka pristigao je 2007. godine, dok je najveći broj naslova za djecu (215) u 313 primjeraka pristigao u 2003. godini. Najviše otkupljenih primjeraka za djecu i odrasle u Gradsku i sveučilišnu knjižnicu Osijek pristiglo je 2001. godine u ukupnom broju od 3253, a najmanji broj otkupljenih primjeraka u ukupnom broju imamo u 1998. godini (304) i 2008. (285).

\subsubsection{Analiza pristiglih naslova i primjeraka u GISKO-u s obzirom na način nabave}

Posljednja tablica u radu daje prikaz broja naslova i primjeraka u istraživanom razdoblju za tri najčešća načina nabave knjiga u Gradskoj i sveučilišnoj knjižnici Osijek, s ciljem analize utjecaja otkupa na izgradnju ukupnog fonda Knjižnice. Iskazani su brojčani pokazatelji za otkup, obvezni primjerak i kupnju. U nastavku su uz pomoć grafičkoga prikaza iskazani postoci za svaki vid nabave pojedinačno 
prema godinama u istraživanom razdoblju te postotak za cjelokupno istraživano razdoblje za ukupan broj naslova i broja primjeraka prema vidu nabave.

Tablica 12. Analiza ukupno pristiglih naslova i primjeraka u GISKO, s obzirom na način nabave: otkup, kupnja, obvezni primjerak - naslovi i broj primjeraka

\begin{tabular}{|l|l|l|l|l|l|l|l|l|l|l|l|l|l|l|l|l|l|l|}
\hline \multicolumn{2}{|l}{ Naslovi } & \multicolumn{1}{l}{ 1998. 1999. 2000. 2001. 2002. 2003. 2004. 2005. 2006. 2007. 2008. 2009. 2010. 2011. 2012. 2013.} \\
\hline Otkup & 262 & 1270 & 319 & 1658 & 1112 & 1720 & 1521 & 1451 & 1065 & 2133 & 285 & 1207 & 851 & 1369 & 963 & 1126 \\
\hline $\begin{array}{l}\text { Kupnja } \\
\text { GISKO }\end{array}$ & 576 & 453 & 947 & 1455 & 1380 & 1725 & 2825 & 2028 & 2270 & 1978 & 2004 & 2189 & 2403 & 2491 & 2626 & 2421 \\
\hline $\begin{array}{l}\text { Obvezni } \\
\text { primjerak }\end{array}$ & 2972 & 2679 & 2894 & 3299 & 4048 & 4576 & 4892 & 4525 & 4401 & 4128 & 4870 & 4700 & 4270 & 4777 & 3428 & 4785 \\
\hline Ukupno & $\mathbf{3 8 1 0}$ & $\mathbf{4 4 0 2}$ & $\mathbf{4 1 6 0}$ & $\mathbf{6 4 1 2}$ & $\mathbf{6 5 4 0}$ & $\mathbf{8 0 2 1}$ & $\mathbf{9 2 3 8}$ & $\mathbf{8 0 0 4}$ & $\mathbf{7 7 3 6}$ & $\mathbf{8 2 3 9}$ & $\mathbf{7 1 5 9}$ & $\mathbf{8 0 9 6}$ & $\mathbf{7 5 2 4}$ & $\mathbf{8 6 3 7}$ & $\mathbf{7 0 1 7}$ & $\mathbf{8 3 3 2}$ \\
\hline
\end{tabular}

\begin{tabular}{|l|l|l|l|l|l|l|l|l|l|l|l|l|l|l|l|l|}
\hline \multicolumn{10}{|l|}{ Primjerci } \\
\hline Otkup & 304 & 1711 & 424 & 3253 & 1657 & 1423 & 1521 & 1565 & 1065 & 2152 & 587 & 1228 & 856 & 1369 & 963 & 1126 \\
\hline $\begin{array}{l}\text { Kupnja } \\
\text { GISKO }\end{array}$ & 3892 & 3129 & 5630 & 9061 & 8587 & 9327 & 12939 & 9072 & 9332 & 7651 & 7712 & 7803 & 9358 & 9433 & 9384 & 9486 \\
\hline $\begin{array}{l}\text { Obvezni } \\
\text { primjerak }\end{array}$ & 2972 & 2679 & 2894 & 3299 & $\mathbf{4 0 4 8}$ & $\mathbf{4 5 7 6}$ & $\mathbf{4 8 9 2}$ & $\mathbf{4 5 2 5}$ & $\mathbf{4 4 0 1}$ & $\mathbf{4 1 2 8}$ & $\mathbf{4 8 7 0}$ & $\mathbf{4 7 0 0}$ & $\mathbf{4 2 7 0}$ & $\mathbf{4 7 7 7}$ & 3428 & $\mathbf{4 7 8 5}$ \\
\hline Ukupno & $\mathbf{7 1 6 8}$ & $\mathbf{7 5 1 9}$ & $\mathbf{8 9 4 8}$ & $\mathbf{1 5 6 1 3}$ & $\mathbf{1 4 2 9 2}$ & $\mathbf{1 5 3 2 6}$ & $\mathbf{1 9 3 5 2}$ & $\mathbf{1 5 1 6 2}$ & $\mathbf{1 4 7 9 8}$ & $\mathbf{1 3 9 3 1}$ & $\mathbf{1 3 1 6 9}$ & $\mathbf{1 3 7 3 1}$ & $\mathbf{1 4 4 8 4}$ & $\mathbf{1 5 5 7 9}$ & $\mathbf{1 3 7 7 5}$ & $\mathbf{1 5 3 9 7}$ \\
\hline
\end{tabular}

Zaključno, najveći broj naslova pristiglih otkupom zabilježen je u 2001. i 2007. godini, kada je on predstavljao $25,9 \%$ od ukupnog broja naslova nabavljenih analiziranim načinima nabave, a najmanji 2008. godine, kada je taj broj naslova činio svega $4 \%$ ukupnoga. U odnosu na cjelokupno istraživano razdoblje, taj udio činio je $16,16 \%$ naslova u odnosu na kupnju i obvezni primjerak. Ako je suditi po broju zaprimljenih naslova, Gradska i sveučilišna knjižnica Osijek ne bi trebala imati većih zamjerki i primjedbi. Ipak, ostaje činjenica da najvažniji kriterij pri izgradnji nekog fonda zasigurno nije broj naslova pristiglih u Knjižnicu.

Slike 1 i 2 prikazuju broj pristiglih naslova prema načinu nabave izražen u postocima. 


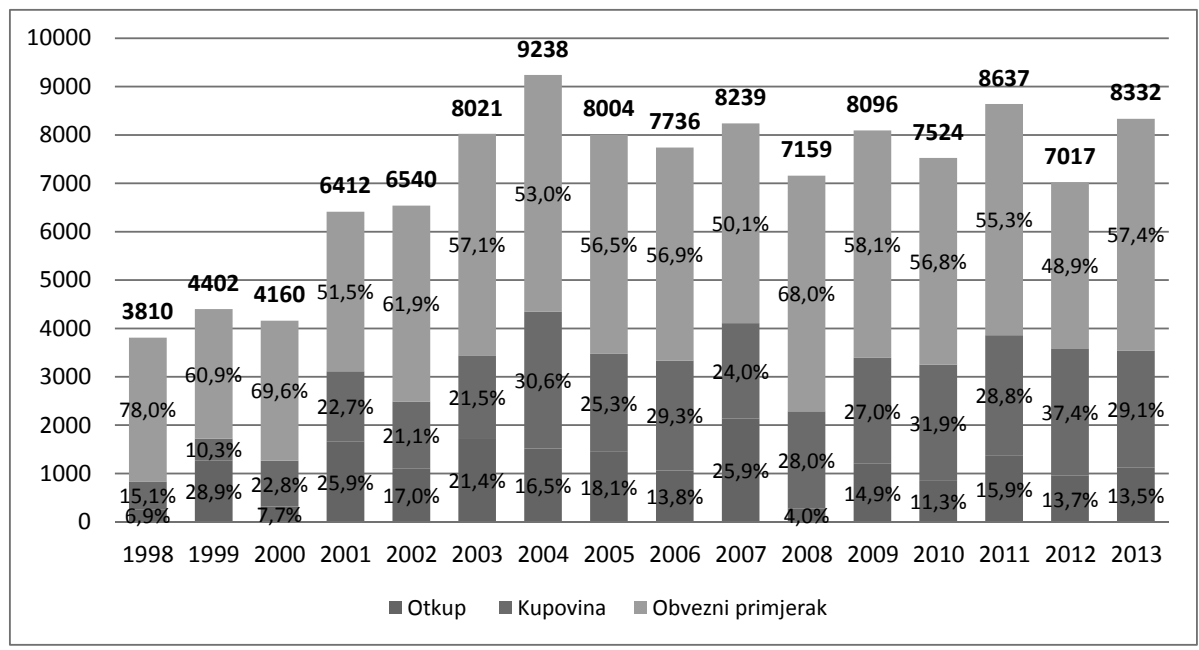

Slika 1. Pristigli naslovi po načinu nabave

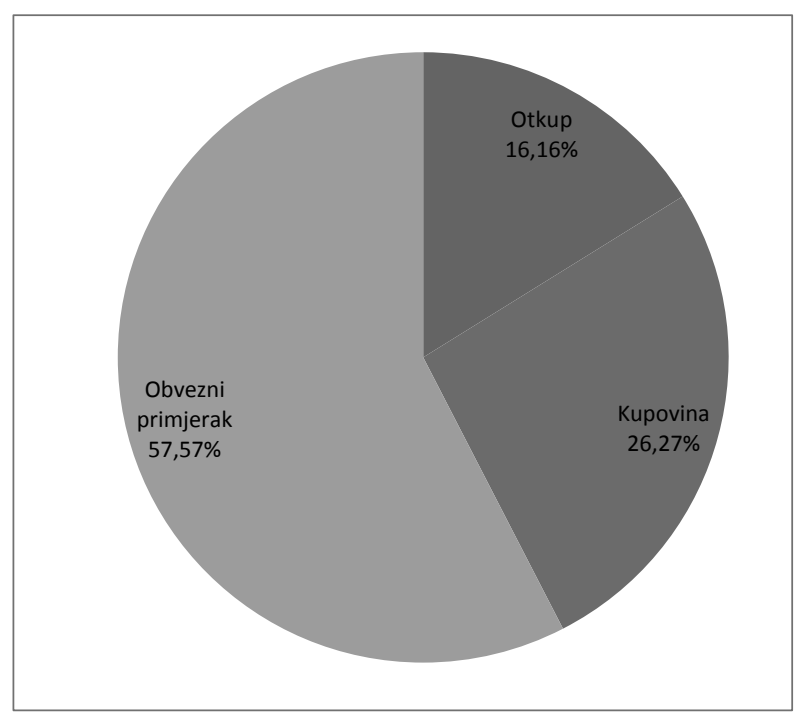

Slika 2. Pristigli naslovi prema načinu nabave 1998.-2013.

Kad je posrijedi broj primjeraka, najveći je zabilježen u 2008. godini $(22,8$ \%), a u 1998. godini najmanji (4,2 \%). Za cjelokupno istraživano razdoblje broj primjeraka pristiglih otkupom činio je svega 9,72 \%. Uzevši u obzir veličinu i značaj Knjižnice, to je zasigurno nedovoljno, osobito ako se prisjetimo osnovnih ciljeva tog načina potpore za narodne knjižnice, koji za zadatak ima otkup izdanja 
domaćih izdavača, i to djela od temeljne vrijednosti za nacionalnu kulturu, znanost i umjetnost, kao i djela koja pridonose boljem upoznavanju različitih kultura te djela hrvatskih autora u prijevodu na strane jezike. Upravo je zbog navedenoga vrednovanje knjižničnih zbirki važan dio upravljanja knjižnicama jer pronalazi i ukazuje na trenutne ili tekuće nedostatke, prednosti i snage, granice i pogreške u oblikovanju zbirke, a uključuje i pronalaženje načina za poboljšanje usluga. ${ }^{37} \mathrm{U}$ konačnici, podaci dobiveni valjanim metodama i tehnikama vrednovanja fonda mogu pomoći knjižničarima da svojim osnivačima i financijerima odgovore na pitanja o tome koliko su učinkovito utrošena dobivena sredstva, koje su jake strane knjižničnog fonda, kolika je korist knjižnice/fonda za zajednicu/korisnike te kakav je knjižnični fond knjižnice. ${ }^{38}$

Slike 3 i 4 prikazuju broj pristiglih primjeraka prema načinu nabave izražen u postocima.

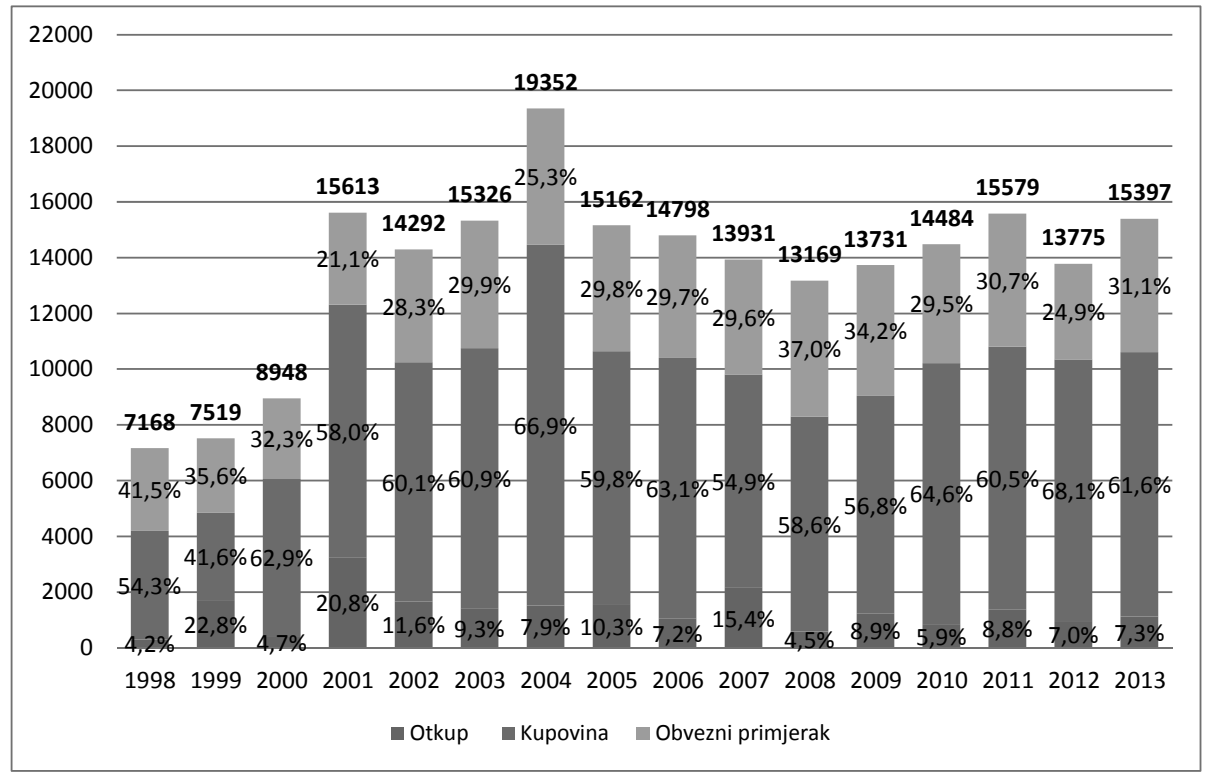

Slika 3. Pristigli primjerci po načinu nabave

37 Dragija, Martina; Aparac-Jelušić, Tatjana. Pristup i metodologija istraživanja o kvaliteti zbirki u knjižnicama visokih učilišta. // Glasnik Društva bibliotekara Split 7, (2000[i.e. 2001]), 167.

38 Pavlinić, Silva; Jasna Horvat. Istraživanje potreba korisnika Gradske i sveučilišne knjižnice Osijek. // Vjesnik bibliotekara Hrvatske 41, 1-4 (1998), 41-61. 


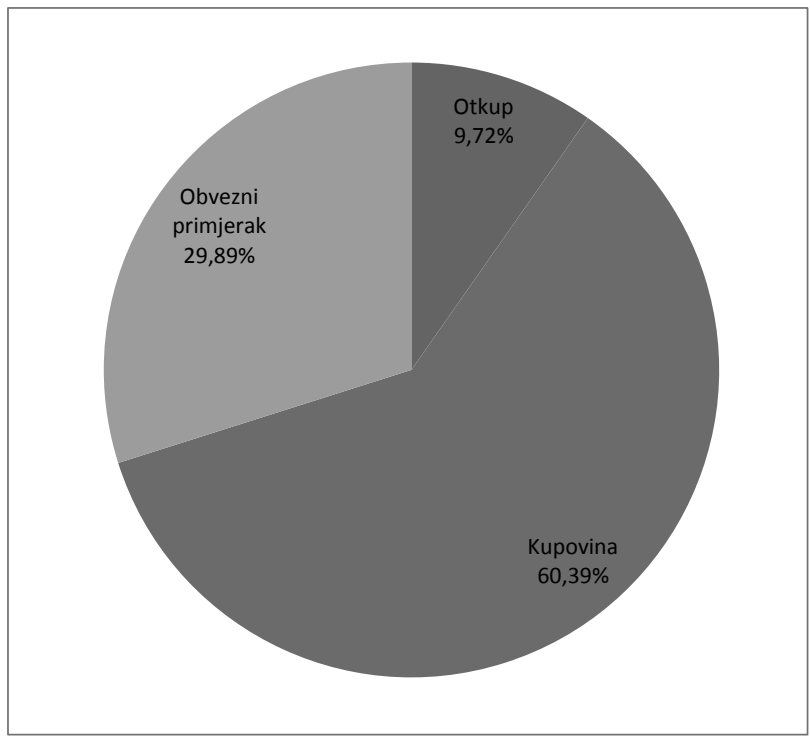

Slika 4. Pristigli primjerci prema načinu nabave 1998.-2013.

\section{Zaključak}

Jedan od najodgovornijih poslova u knjižnicama jest nabava knjižne građe. Utvrdili smo da ona mora biti rezultat stručnih procjena knjižničara temeljenih na standardima, utvrđenoj strukturi i pomnim analizama postojećeg fonda, potreba korisnika, ali i financijskih mogućnosti knjižnice te ponude nakladnika. Analizom postupanja pri otkupu Ministarstva kulture također smo utvrdili mnoge probleme koji su tijekom cijeloga istraživanog razdoblja ostali gotovo neizmijenjeni. Manjim vidljivijim pomacima pri postupanju i izvješćivanju pri otkupu građe svjedočimo tek početkom 2014. godine, kada službe Ministarstva pokušavaju postići bolju kontrolu nad izdavačima, ali i ujednačiti izvješćivanja koristeći tehnološki naprednije i jedinstvene obrasce. Na taj način dobili smo mogućnost pretraživanja priloženih obrazaca, što ujedno štedi vrijeme stručnog knjižničnog osoblja, ali i omogućava bolje snalaženje u priloženim popisima Ministarstva.

S druge strane, budući da ministarstva otkupom knjiga za narodne knjižnice žele povećati dostupnost pisane riječi te promicati kulturu čitanja s ciljem afirmacije književnosti kao jedne od vodećih grana kulturne produkcije, smatrali smo kako je potrebno izvršiti analizu prispjele građe želeći utvrditi uspješnost provedbe tog načina izgradnje fonda. Analiza je pokazala kako je Gradska i sveučilišna knjižnica Osijek otkupom obogatila svoj fond, ali i dalje vjerujemo da je takav način nabave ograničio samostalnost odabira knjiga za nabavu, a ujedno, posredno, $\mathrm{i}$ 
umanjio profesionalnu odgovornost knjižničara za izgradnju zbirke. Predstavljeni podaci pokazuju nam da su najzastupljeniji romani/pripovijetke bili 2002. u odnosu na druge rodove: brojčano izraženo, riječ je o 148 naslova (239 primjeraka), a zatim u 2001. godini 145 naslova (300 primjerka). Ukupno gledajući, 2001. godina u odnosu na sve rodove prednjači s otkupljena 402 naslova ( 807 primjeraka). Iz analize podataka također je vidljivo kako su tijekom promatranoga razdoblja otkupa najmanje zastupljeni eseji, pisma i satira.

U razdoblju od 1998. do 2013. godine ukupan udio otkupa čini 16,16 \% prema broju naslova, a $9,72 \%$ prema broju primjeraka u cjelokupnom fondu nabavljenom kupnjom, obveznim primjerkom i otkupom u Gradskoj i sveučilišnoj knjižnici Osijek.

Vjerujemo da je stimuliranje nakladništva otkupom samo djelomično zadovoljilo nakladnike. „Bolju budućnost nakladništva u Hrvatskoj, pa tako i 'malih' nakladnika, moguće je nazrijeti u iznalaženju novog modela financiranja izdavaštva (jer u slučaju eventualne pojačane kupovne moći ostaje problem ograničenog tržišta), u poticanju kulture čitanja kroz nacionalne programe te u novom modelu financiranja knjižnica kojim bi samostalno raspolagale (opsegom značajnije većim) sredstvima za nabavu građe slijedom istraženih i utvrđenih potreba svojih korisnika. Treba također zakonski pojačati i značajnije financirati zadaće nakladnika i knjižnica u odnosu na tekuće obznanjivanje podataka o tiskarskoj produkciji.“39

Istraživanje je ukazalo na brojne pozitivne, ali i neke negativne aspekte poslovanja Knjižnice, s obzirom na perspektivu otkupa Ministarstava. Važno je i dalje ulagati energiju i nastaviti s dobrom praksom koja je već prepoznata kao kvalitetan aspekt poslovanja te učiniti sve što je moguće kako bi se poboljšali negativno percipirani aspekti istraživanja. Zaključni prijedlog koji dajemo na kraju ovoga istraživanja jest provođenje kontinuiranog mjerenja zadovoljstva uslugama, kao i promjene pri postupanju s otkupljenom građom koje bi poboljšale ukupne kvalitete prikazane preko izgradnje kvalitetnih knjižničnih zbirki. Moguće je da svaka od uključenih strana najbolje radi svoj posao i da sama po sebi teško može mijenjati kontekst. No za to postoje razmjena mišljenja i razgovor. Samo ćemo tako u budućnosti moći odgovoriti na pitanje jesmo li za ili protiv otkupa.

\section{LITERATURA}

Anić, Vladimir. Riječnik hrvatskoga jezika. Zagreb : Novi liber, 1994.

Aparac-Jelušić, Tatjana. Sveučilišni bibliotečni sustavi u teoriji i praksi. // Vjesnik bibliotekara Hrvatske 33, 1-4 (1990), 43-51.

39 Jelušić, Srećko. Kako objaviti i preživjeti. // Knjiga, knjižnice, nakladnici i zakoni : sažeci / Međunarodni kolokvij o pravnom položaju knjige, knjižnica i nakladništva u Republici Hrvatskoj. Zagreb: Hrvatsko bibliotekarsko društvo, 1996. Str. 26-27. 
Aparac-Jelušić, Tatjana. Utjecaj promjena u akademskom obrazovanju na preoblikovanje knjižničnih službi i usluga. // Glasnik Društva bibliotekara Split 7(2000), 39-51.

Aparac-Jelušić, Tatjana. Izgradnja i upravljanje knjižničnim fondom: predavanje. Rijeka, 2003. [citirano 2017-04-08]. Dostupno na https://goo.gl/3i8UPC

Clayton, Peter; Gary E. Gorman. Managing information resources in libraries : collection management in theory and practice. London : Library Association Publishing, 2001.

Članovi Kulturnog vijeća za knjižnu, nakladničku i knjižarsku djelatnost. [citirano: 2017-04-08]. Dostupno na http://www.min-kulture.hr/default.aspx?id=191

Dragija, Martina; Tatjana Aparac-Jelušić. Pristup i metodologija istraživanja o kvaliteti zbirki u knjižnicama visokih učilišta. // Glasnik Društva bibliotekara Split 7(2000), 164-165.

Izdavačka djelatnost, skupovi, udruge i programi popularizacije znanosti [citirano: 2017-04-08]. Dostupno na http://public.mzos.hr/Default.aspx?art=14718

Javni poziv za otkup knjiga i časopisa za narodne knjižnice [citirano: 2017-04-08]. Dostupno na http://www.min-kulture.hr/default.aspx?id=11744

Javni poziv za predlaganje programa književne, nakladničke i knjižarske djelatnosti za 2014. godinu u okviru programa javnih potreba u kulturi Republike Hrvatske [citirano: 2017-04-08]. Dostupno na http://www.min-kulture.hr/novost/default. aspx?id=10387

Jelušić, Srećko. Kako objaviti i preživjeti. // Knjiga, knjižnice, nakladnici i zakoni : sažeci / Međunarodni kolokvij o pravnom položaju knjige, knjižnica i nakladništva u Republici Hrvatskoj. Zagreb: Hrvatsko bibliotekarsko društvo, 1996. Str. 26-27.

Kriteriji za financijsku porporu izdavanja znanstvenih knjiga. [citirano: 2017-04-08] . Dostupno na https://mzo.hr/sites/default/files/migrated/kriteriji_2015.pdf

Leonhardt, Thomas. The gifts and exchange function in ARL libraries: now and tomorrow. // Library Acquisitions : Practice \& Theory 21, 2(1997), 141-149.

Lewis, Janice S. An assessment of publisher quality by political science librarians. // College \& Research Libraries 61, 4(2000), 313-323.

Otkup knjiga - pregleda sa stanjem u 2013. g. [citirano: 2017-04-08]. Dostupno na http://www.min-kulture.hr/default.aspx?id=8912

Pavlinić, Silva; Jasna Horvat. Istraživanje potreba korisnika Gradske i sveučilišne knjižnice Osijek. // Vjesnik bibliotekara Hrvatske 41, 1-4 (1998), 41-61.

Peleš, Gajo. Nabavna politika kao pokazatelj odnosa između sveučilišnih (fakultetskih) biblioteka i Nacionalne i sveučilišne biblioteke. // Vjesnik bibliotekara Hrvatske 33, 1/4(1990), 53-56.

Preporuke za knjižnično zakonodavstvo i politiku u Europi. // Vjesnik bibliotekara Hrvatske 43, 3(2000), 161-162. 
Sečić, Dora. Neki suvremeni pogledi na nabavnu politiku u znanstvenim bibliotekama u SAD i Evropi. // Informatologia Yugoslavica 20, 3-4(1988), 199-202.

Shera, Jesse H. Introduction to library science. Littleton, Colorado : Libraries Unlimited, 1976.

Standardi za narodne knjižnice u Republici Hrvatskoj. // Narodne novine 58, 1071(1999). [citirano: 2017-09-04]. Dostupno na http://narodne-novine.nn.hr/clanci/sluzbeni/1999_06_58_1071.html

Standard za visokoškolske knjižnice u Republici Hrvatskoj. // Vjesnik bibliotekara Hrvatske 33, 1-4(1990), str. 201-210.

Zakon o knjižnicama. // Narodne novine 105, 1616(1997). [citirano: 2017-09-04]. Dostupno na http://narodne-novine.nn.hr/clanci/sluzbeni/1997_10_105_1616.html

Zakon o visokim učilištima (pročišćeni tekst). // Narodne novine 59, 1187(1996). [citirano:2017-09-04]. Dostupno na http://narodne-novine.nn.hr/clanci/sluzbeni/1996_07_59_1187.html 